\title{
Autophagy in Tenebrio molitor Immunity: Conserved Antimicrobial Functions in Insect Defenses
}

\author{
Yong Hun Jo ${ }^{1}$, Jung Hee Lee ${ }^{1}$, Bharat Bhusan Patnaik ${ }^{2}$, Maryam Keshavarz ${ }^{3}$, \\ Yong Seok Lee ${ }^{4}$ and Yeon Soo Han ${ }^{1 *}$
}

1 Department of Applied Biology, Institute of Environmentally-Friendly Agriculture (IEFA), College of Agriculture and Life Sciences, Chonnam National University, Gwangju, South Korea, 2 P. G. Department of Biosciences and Biotechnology, Fakir Mohan University, Balasore, India, ${ }^{3}$ Department of Evolutionary Biology, Institute for Biology-Zoology, Free University of Berlin, Berlin, Germany, ${ }^{4}$ Department of Biology, College of Natural Sciences, Soonchunhyang University, Asan City, South Korea

\section{OPEN ACCESS}

Edited by:

Jere W. McBride,

University of Texas Medical Branch at Galveston, United States

Reviewed by: Fengliang Jin, South China Agricultural University,

China

Chaozheng Li,

Sun Yat-Sen University, China

${ }^{*}$ Correspondence: Yeon Soo Han hanys@jnu.ac.kr

Specialty section: This article was submitted to Microbial Immunology, a section of the journal Frontiers in Immunology

Received: 14 February 2021 Accepted: 13 May 2021

Published: 31 May 2021

Citation:

Jo YH, Lee JH, Patnaik BB, Keshavarz M, Lee YS and Han YS (2021) Autophagy in Tenebrio molitor Immunity: Conserved Antimicrobial

Functions in Insect Defenses.

Front. Immunol. 12:667664. doi: 10.3389/fimmu.2021.667664
The yellow mealworm beetle (Tenebrio molitor) has been exploited as an experimental model to unravel the intricacies of cellular and humoral immunity against pathogenic infections. Studies on this insect model have provided valuable insights into the phenotypic plasticity of immune defenses against parasites and pathogens. It has thus been possible to characterize the hemocoelic defenses of $T$. molitor that rely on the recognition of non-self-components of pathogens by pattern recognition receptors (PRRs). The subsequent signaling cascade activating pathways such as the NF- $\kappa B$ controlled by Toll and IMD pathways lead to the synthesis of antimicrobial peptides (AMPs), onset of hemocyte-driven phagocytosis, and activation of the prophenoloxidase cascade regulating the process of melanization. Nevertheless, the activation of autophagy-mediated defenses of $T$. molitor against the facultative intracellular gram-positive bacterium Listeria monocytogenes provides clear evidence of the existence of a cross-talk between autophagy and the IMD pathway. Moreover, the identification of several autophagy-related genes (Atgs) in T. molitor transcriptome and expressed sequence tag (EST) databases has contributed to the understanding of the autophagy-signaling cascade triggered by L. monocytogenes challenge. Providing further evidence of the cross-talk hypothesis, TmRelish has been shown to be required not only for regulating the synthesis of AMPs through the PGRP-LE/ IMD pathway activation but also for the expression of Atgs in $T$. molitor larvae following $L$. monocytogenes challenge. Notably, L. monocytogenes can stimulate the T. molitor innate immune system by producing molecules recognized by the multifunctional PRR (TmPGRP_ LE), which stimulates intracellular activation of the IMD pathway and autophagy. Considering the conservation of autophagy components involved in combating intracellular pathogens, it will be interesting to extrapolate a dynamic cross-talk model of immune activation. This review summarizes the most significant findings on the regulation of autophagy in $T$. molitor during $L$. monocytogenes infection and on the role of the innate immunity machinery, including the NF$\kappa \mathrm{B}$ pathway, in the control of pathogenic load.

Keywords: Tenebrio molitor, Listeria monocytogenes, autophagy, NF-kappaB, innate immunity 


\section{INTRODUCTION}

Autophagy is well-known as a conserved cellular mechanism by which the cell degrades unnecessary and/or dysfunctional cellular components through the action of lysosomes. It maintains homeostasis during cellular stress and pathogen or infective organism invasion. For instance, under nutrient starvation, oxidative stress, and intracellular pathogen invasion, the autophagic machinery is activated in order to detoxify cells and maintain a surveillance of cellular components for intensified cell function $(1,2)$. Further, in coordination with apoptosis regulator $\mathrm{Bcl}-2$, the autophagy protein Beclin-2 inhibits apoptosis in normal physiological and pathological conditions (3).

There are three known forms of autophagy, namely microautophagy, macroautophagy and chaperone-mediated autophagy (CMA). Although all the autophagy forms culminate in the lysosomal degradation of cellular cargo including viruses intracellularly they are distinguished from one another on the basis of the pathway by which the cargo is delivered to the lumen of the autolysosome (4). Microautophagy is initiated by a direct and random invagination of a membrane around a portion of the cytoplasm that subsequently differentiates into an autophagic tube to enclose portions of the cytosol (5). The much well-studied and conserved macroautophagy mechanism in eukaryotes requires the formation of a double-membrane vesicular structure called the autophagosome (6). In this process, targeted cellular components are isolated from the rest of the cellular cytosolic components within the newly developing autophagosome. Subsequently, the autophagosome fuses with the lysosome to form the autolysosome in which the enclosed cellular components are degraded and/or recycled (Figure 1). In yeast, the autophagosome formation is mediated by the hierarchical recruitment of autophagy-related (Atg) proteins to the phagophore assembly site or preautophagosomal structure (PAS). In contrast, PAS-like structure have not been identified in mammals, wherein multiple cellular organelles serve as origins for the assembly of the phagophore $(7,8)$. Consequent upon the recruitment of Atg proteins, the phagophore gets extended to form an autophagosome. Upon maturity, the autophagosome are transported along the endocytic pathway before fusing with the lysosomes to form autophagolysosome. Subsequently, the cellular cargos are degraded by the hydrolytic enzymes of lysosomes and degradation products are released back to the cytoplasm for cell use (9). Viruses such as the Severe acute respiratory syndrome coronavirus 2 (SARS-CoV-2) escape the macroautophagy regulatory cascade as the viral protein ORF3a block the fusion of the autophagosome to the lysosome, thus evading eventual degradation (10). With the exception of SARS$\mathrm{CoV}-2$, the autophagy regulatory cascade involving Atg genes have been found to be receptive to vesicular stomatitis virus (VSV), Rift Valley fever virus (RVFV) or Zika virus infection in Drosophila model $(11,12)$. In contrast, the dengue virus (DENV2) titers in mosquito Aedes aegypti Aag2 cells were not affected in Atg silenced individuals suggesting diverse autophagic response in insects (13). In CMA, all proteins containing the pentapeptide motif 'KFERQ' in their amino acid sequences are selectively recognized by a specialized cytosolic chaperone known as the heat shock cognate protein of $70 \mathrm{kDa}$ (HSC70) (14). The resulting complex is targeted to the lysosomal membrane where it binds to a receptor called lysosome-

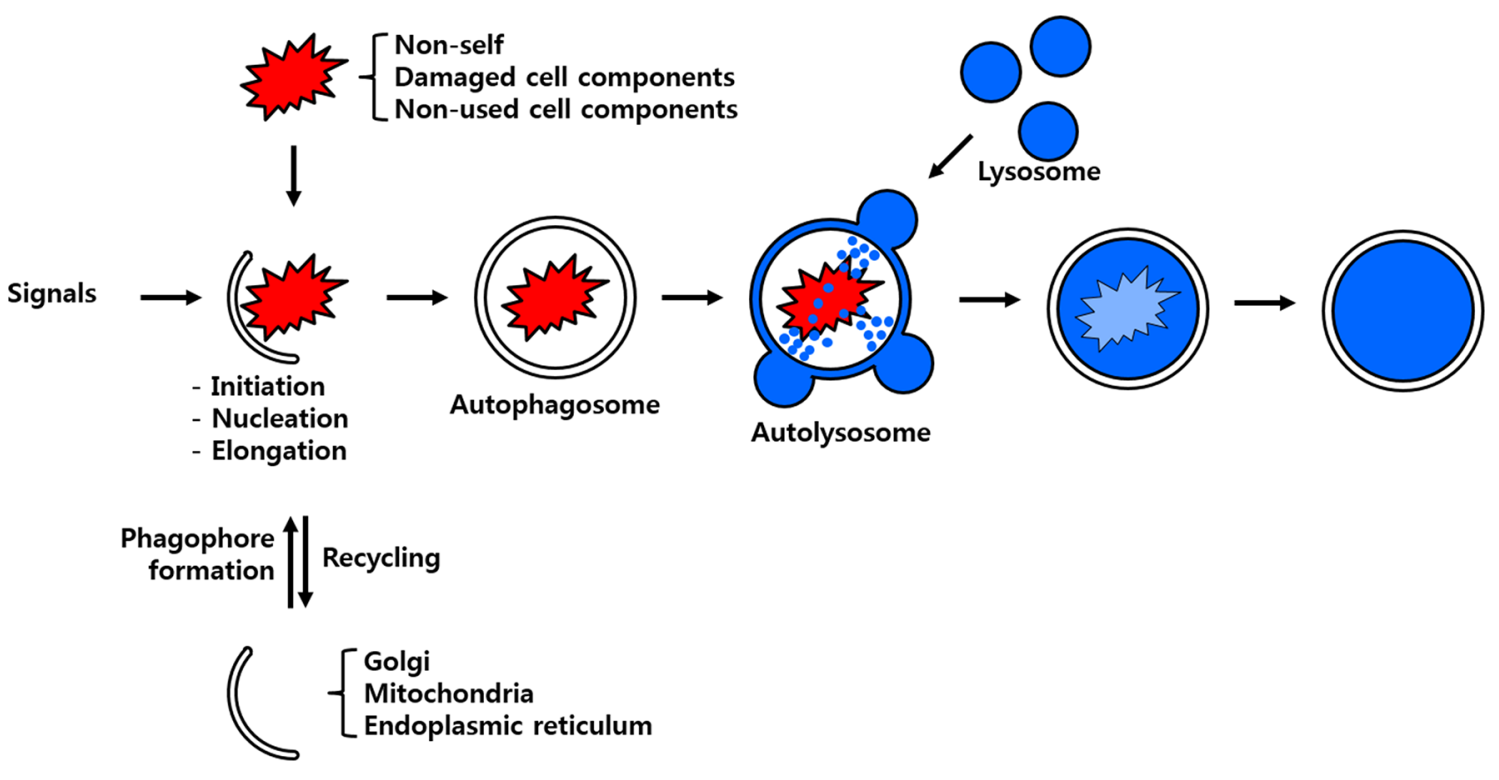

FIGURE 1 | Scheme of the process of autophagy. Non-self-entities such as pathogenic bacteria and unused or damaged cell components are enclosed by membrane particles believed to stem from the Golgi apparatus, mitochondria and/or endoplasmic reticulum. The developing autophagosome fuses with the lysosome to deliver its cargo to hydrolytic enzymes for eventual degradation and/or recycling. 
associated membrane protein type 2A (LAMP-2A) (5). The presence of a luminal form of HSC70 (lys-HSC70) is required for the complete translocation of the chaperone-associated target protein complex into the lysosomal lumen for its eventual degradation.

In this review, we focused on the regulatory autophagy signaling cascade (illustrating macroautophagy) in the yellow mealworm, Tenebrio molitor and its putative role in the host during Listeria monocytogenes infection. Further, a cross-talk mechanism of autophagy process and the NF- $\mathrm{\kappa B}$ pathway in $T$. molitor in response to invasion of infective microorganisms have been suggested.

\section{MECHANISM AND REGULATION OF AUTOPHAGY}

Macroautophagy (here-after referred to as autophagy) is a highly regulated process that can be conveniently divided into three major steps: autophagy induction (or initiation), vesicle nucleation, and vesicle expansion (or elongation) and completion.

\section{Autophagy Induction and Formation of the Initiation Complex}

The induction of autophagy is triggered by a variety of stress cues that include, but are not limited to, nutrient deprivation, hypoxia, endoplasmic reticulum (ER) stress, and oxidative stress (15). In most cases, these stimuli trigger autophagy induction through activation of the nutrient energy sensor AMP-activated protein kinase (AMPK) or inhibition of the negative regulator of autophagy target of rapamycin (TOR) (15). Among the several pathways mediating the transmission of autophagic signals, the TOR-dependent autophagic pathway is relatively well-characterized. The detailed description of TORdependent autophagic pathway is discussed in Figure 2.

In eukaryotes, autophagy induction is achieved through Atg1 [insect homolog of unc-51 like autophagy activating kinase 1 (ULK1)] complex formation, following inactivation of its upstream negative regulator TOR (Figure 2). However, there are significant differences in the composition and function of the core components of the Atg1 complex among yeast, mammals, and insects (16). In yeast, for example, Atg1 interacts with at least eight other Atg proteins and TOR regulates the formation of Atg1-Atg13-Atg17 complex (17). Conversely, humans and Drosophila do not possess clear orthologs of Atg17 or its interacting proteins Atg29 and Atg31 (16, 18, 19). Instead, the mammalian Atg1 ortholog ULK1 forms a complex with Atg13 and two additional proteins Atg101 and the focal adhesion kinase family-interacting protein of $200 \mathrm{kDa}$ (FIP200), both of which are required for autophagosome formation. Furthermore, while TOR-mediated phosphorylation of Atg13 must be suppressed to allow Atg13 to interact with and activate Atg1 in yeast, the mammalian and Drosophila orthologs of Atg13 are associated with ULK1. Moreover, in Drosophila, Atg13 becomes hyper-phosphorylated upon autophagy induction (20). In addition, overexpression of Drosophila Atg1 has been shown to induce autophagy; whereas overexpression of ULK1 inhibits autophagy $(21,22)$. The proposed explanations for this difference include the influence of additional regulatory proteins and the existence of feedback regulation between Atg1 and $\operatorname{TOR}(16,17)$.

\section{Vesicle Nucleation}

Vesicle nucleation starts with the recruitment of yeast Atg proteins, or their equivalents in higher animals, to the PAS. The mechanism regulating this process is not yet clear, but the activation of the class III phosphatidylinositol 3-kinase (PI3K) complex is indispensable (20). In fact, following autophagy induction by the activated Atg1/ULK1 complex, a structure enriched in phosphatidylinositol-3-phosphate [PI3P, also known as PtdIns (3)P] appears at the site of autophagosome formation (16).

PI3P is synthesized by enzymes of the PI3K family, which phosphorylate the 39-hydroxyl group on the inositol ring of phosphoinositides (23). Three classes of PI3K enzymes are known: class I enzymes are composed of p100 catalytic subunits and p85 adaptors: class II enzymes are large (> 200 $\mathrm{kDa}$ ) and characterized by a C2 domain at the C-terminus; finally, class III enzymes are homologous to the vacuolar protein sorting 34 (Vps34), the only PI3K characterized in yeast (23). In yeast, Vps34 can form complexes with other autophagic components such as Atg6, Atg14, and Vps15. The mammalian orthologs of such proteins have been named Vps34, Beclin-1, Atg14, and p150, respectively (24).

In higher animals, complexes formed by class I PI3Ks are considered negative regulators of autophagy. For example, the activation of class I PI3Ks by the insulin receptor leads to phosphorylation of plasma membrane lipids, which in turn recruit and activate Akt/protein kinase $\mathrm{B}(\mathrm{PKB})$, a downstream negative regulator of autophagy (25). In contrast, complexes formed by class III PI3Ks are divided into several types depending on the proteins that interact with the core components, namely Atg6 or Beclin, Vps34 and Vps15 (20). Proteins such as UV-resistance associated gene (UVRAG), activating molecule in Beclin-1-regulated autophagy (AMBRA1), Atg14L, and Bax-interacting factor-1 (Bif-1) are known to positively regulate autophagy when interacting with the core complex proteins. Conversely, other proteins interacting with class III PI3Ks such as run domain Beclin-1-interacting and cysteine-rich containing protein (Rubicon), Cln-2, and Bcl- $\mathrm{x}_{\mathrm{L}}$ are negative regulators of autophagy $(16,24,26,27)$.

Although PI3P production is essential for autophagosome formation, its exact role in phagophore formation is yet to be deciphered. It has been proposed that PI3P production is involved in altering the composition of the ER-derived lipid bilayer to create a phagophore or simply in the recruitment of PI3P-binding proteins that are required for the synthesis of the phagophore (28). For instance, the autophagy proteins Atg18 and Atg21 are known to be recruited by PI3P to the developing phagophore. Moreover, in yeast, Atg18 can form a complex with Atg2, which localizes to the PAS depending on the PI3P-binding ability of Atg18 (29). 


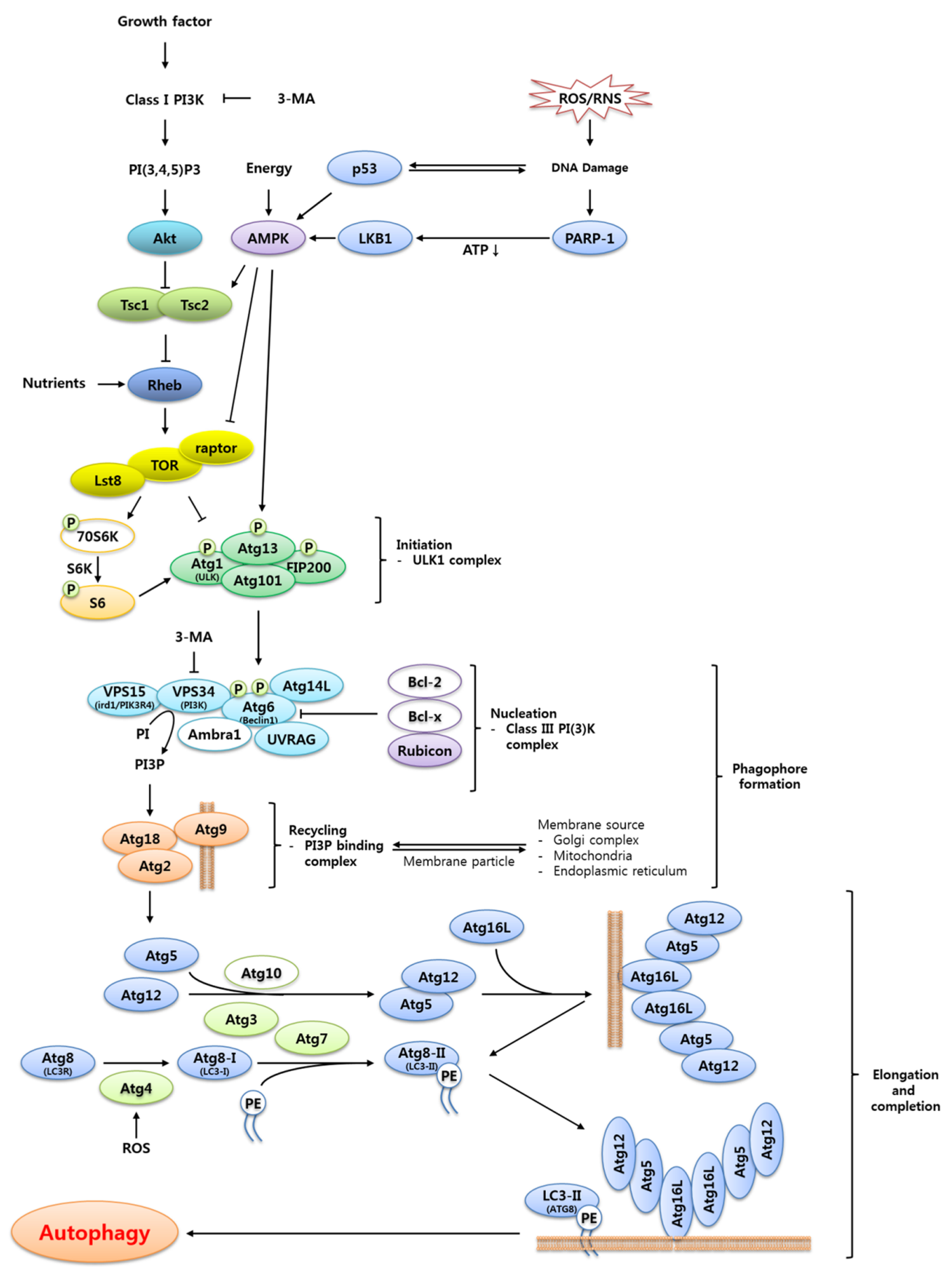

FIGURE 2 | Proposed signaling cascade triggering TOR-regulated autophagy in T. molitor. Most of the autophagy-related genes included in the scheme were identified in the T. molitor RNA-Seq and EST databases. Growth factors such as the insulin receptor and nutrient-rich conditions negatively regulate autophagy, while reactive oxygen/nitrogen species (ROS/RNS), DNA damage and a low cellular energy status (that is, a high AMP/ATP ratio) induce autophagy. Upon generation of autophagy signals by the appropriate stimuli, an initiation complex comprising Atg1, Atg13, Atg101 and Fip200 is formed. Subsequently, the nucleation complex consists of the Vps15-Vps34-Atg6-Atg14-UVRAG complex, alternatively named Class III PI (3)K complex. In addition, the Atg2-Atg18 complex supports the delivery of the membrane particles from the Golgi, mitochondria or endoplasmic reticulum. Vesicle elongation is carried out by two ubiquitin-like complexes: the Atg5-Atg12: Atg16 complex, generated through the E1- and E2-like enzymatic activity of Atg7 and Atg10, respectively; and the Atg8-PE complex, generated by the proteolytic activity of Atg4 before transfer of Atg8 to the E1- and E2-like enzymes Atg7 and Atg3, respectively. Open circles show either non-Atg components (3-MA, PI3P, Class I PI3K, PI(3,4,5)P3 and PE) or autophagy related genes (70S6K, Bcl-2, Bcl-x, Ambra1 and Atg10) unidentified in T. molitor. 
The appearance of a developing phagophore is crucial for the completion of the vesicle nucleation step. However, the exact source of the developing phagophore is unknown. Nevertheless, two proposed models have received considerable scientific support. The first model suggests that the phagophore is synthesized by a de novo mechanism and expands through the addition of lipids from other sources, transported to the site by Atg9 (30). The second model suggests that the initial cradle for the formation of the phagophore is derived from a subdomain of the ER and later expands between the ER domains to which it is physically linked $(31,32)$. However, there is an increasing body of literature that implicates several other intracellular organelles, including the Golgi apparatus, endosomes, mitochondria and the plasma membrane as sources of initial building material for the phagophore (16, 33-35). The mechanism for determining the site of phagophore formation within the cytosol of higher eukaryotes is also not well understood. In yeast, the PAS functions as an organizing center for autophagosome formation because most of the Atg proteins necessary for the formation of the developing phagophore are usually recruited to the PAS (16). It is not clear, however, if an equivalent of the PAS does exists in higher eukaryotes.

\section{Vesicle Expansion and Completion}

In the canonical autophagy machinery, vesicle expansion and completion involve at least eight Atg proteins. These proteins are grouped into two major sets according to their functional participation in ubiquitin-like conjugation reactions. In particular, Atg5-Atg12/Atg16 complex requires Atg7 and Atg10 as E1and E2-like enzymes, respectively. Similarly, Atg8-[known as microtubule-associated protein 1 light chain 3 (LC3) in mammals]-phosphatidylethanolamine (PE) complex requires the proteolytic activity of Atg4 together with the E1- and E2-like enzymatic activity of Atg7 and Atg3, respectively. The Drosophila genome contains two orthologs of the yeast Atg8, denoted as Atg8a and Atg8b. Similarly, the human genome includes four orthologs with high sequence identity to the yeast Atg4.

The regulation of vesicle expansion and completion is mediated by the activity of two highly conserved ubiquitin-like protein complexes, namely Atg5-Atg12/Atg16 complex and Atg8-PE complex. In the Atg5-Atg12/Atg16 complex, Atg12 is a ubiquitin-like protein containing a C-terminal glycine residue. $\operatorname{Atg} 12$ is first activated by the E1-like enzyme Atg7, which transfers it to the E2-like enzyme Atg10. In turn, Atg10 catalyzes the covalent binding of the $\mathrm{C}$-terminal glycine residue of Atg12 to a lysine residue of Atg5 (36). The Atg12-Atg5 complex then associates non-covalently with Atg16; such interaction is required for the localization of the Atg12-Atg5 complex to the PAS $(37,38)$.

The formation of the Atg8-PE complex is accomplished through the conjugation of the ubiquitin-like protein Atg8 to the head-group of a membrane PE lipid molecule. Atg8 is normally synthesized with a C-terminal arginine residue masking the penultimate $\mathrm{C}$-terminal glycine residue. Due to the proteolytic activity of Atg4, such arginine is removed, thus exposing the glycine residue to the activity of the ubiquitin-like enzyme. The cleaved Atg8 is then transferred to Atg7, which in turn transfers Atg8 to Atg3, an E2-like enzyme. Next, Atg3 transfers Atg8 to a membrane PE. The resulting Atg8-PE complex is thought to mediate membrane tethering, thereby assisting the expansion of the isolation membrane through the promotion of vesicle carrier fusion (39). In particular, the inhibition of the Atg8 conjugation system in mammalian cells has been shown to lead to failure of isolation -membrane closure into a complete autophagosome (38), suggesting that Atg8 is responsible for the late step of autophagosome formation.

Based on the above-mentioned findings, it is noted that the hierarchical functioning of several Atg proteins are crucial towards regulation of autophagic machinery in eukaryotes. In addition to the extensively studied yeast autophagy model, considerable work on autophagy has been carried out in mammalian and Drosophila model systems (16). The autophagy pathway induced by various pathogens (Mycobacteria and virus) and PAMPs (PGN, LPS and ssRNA) has been nicely illustrated in humans (Figure 3) $(40,41)$. However, autophagy research in the beetle, T. molitor is still in its infancy. Therefore, an attempt has been made to review the identification and characterization of Atg protein orthologs in T. molitor and the role during host-pathogen interactions.

\section{CONSERVATION OF THE AUTOPHAGY SYSTEM IN T. MOLITOR}

The sequences of the Atg genes of Drosophila were used as query against unpublished RNA sequencing (RNA-Seq) and expressed sequence tag (EST) sequence databases of T. molitor to identify Atg genes in T. molitor (42). After confirmation of search results via local-TBLASTN analysis, the candidate T. molitor Atg genes were grouped based on their functional location along the autophagy signaling pathway. The genes were thus placed within the categories "upstream signaling", "initiation of autophagy", "vesicle nucleation", and "vesicle expansion and completion".

\section{Upstream Genes Regulating Autophagy Induction in T. molitor}

A total of 13 genes putatively involved in the regulation of autophagy induction upstream of/or in conjunction with TOR, a central cell growth regulator that integrates signals from growth factors and nutrient dynamics (43), were identified in T. molitor. These candidate genes are presented along with their orthologs in humans, yeast (Saccharomyces cerevisiae S288c) and Drosophila in Table 1. Except for liver kinase B1 (Lkb1) and p53, which were only detected in the T. molitor EST database, the rest other genes were identified in both the T. molitor RNA-Seq and EST databases. Notably, TOR is present in two copies (TOR1 and TOR2) in the genome of yeast, whereas only one copy of this gene has been characterized in humans, Drosophila, and $T$. molitor. Furthermore, putative orthologs of all other genes of Drosophila and humans belonging to the category, "upstream regulatory genes" were identified in T. molitor. However, homologs of genes such as $p 53$, poly-(ADP-ribose) polymerase (Parp), Tuberose sclerosis 1 (Tsc1) and Tsc2 have not been characterized in yeast, despite having been identified from humans and T. molitor. 


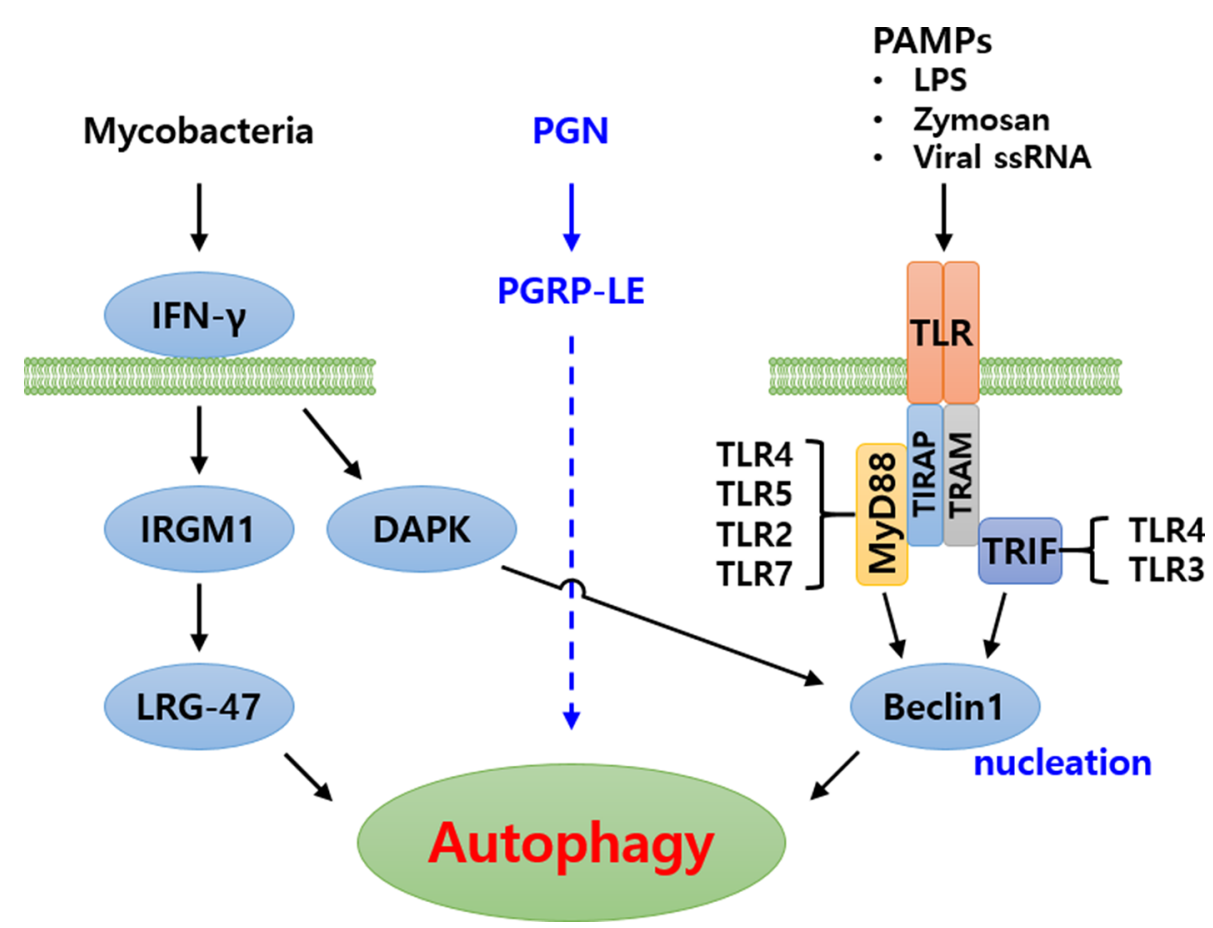

FIGURE 3 | Schematic representation of autophagy signaling cascade induced by pathogenic bacteria in humans. Three major signaling cascades have been identified. In the first, Mycobacteria are recognized by IFN- $\gamma$, subsequently inducing autophagy. In the second, bacterial peptidoglycans (PGN) are recognized by PGRP-LE and induce autophagy. The signaling cascade is yet to be identified. In the third cascade, Pathogen associated molecular patterns (PAMPs) are recognized by Toll-like receptor forming Toll-MyD88-TIRAP complex or Toll-TRIF-TRAM complex, intracellularly. These complexes subsequently signal to Beclin1 (Atg6) for induction of autophagy.

\section{Genes Involved in Autophagy Initiation in T. molitor}

The composition of the autophagy initiation complex varies among eukaryotes although two of its components, the yeast Atg1 and Atg13, have orthologs conserved in both insects and mammals. A total of four genes putatively required for the formation of the initiation complex in higher eukaryotes, namely Atg1, Atg13, Atg101 and FIP200, were identified by screening the T. molitor RNA-Seq database (Table 2). Orthologs of all these candidate genes were also found in representative higher eukaryotes such as Drosophila and humans.

Two additional genes required for the formation of the initiation complex in yeast, Atg29 and Atg31 (16) were not characterized in higher eukaryotes including T. molitor. Similarly, Atg17, whose protein product is required for the formation of the initiation complex in yeast, is not known to have clear orthologs in higher eukaryotes. However, a nonorthologous functionally equivalent gene, FIP200, existing in both Drosophila and humans was also identified in T. molitor.

\section{Genes Involved in Vesicle Nucleation in T. molitor}

In yeast, vesicle nucleation during autophagy is achieved through the regulatory activity of a complex consisting of Vps34 and three other proteins: Vps15, Vps30/Atg6 and Atg14. The mammalian orthologs of these proteins have been identified and named Vps34, p150, Beclin-1 and Atg14 (24). Orthologs of these proteins have also been identified in the RNA-Seq database of T. molitor. Putative orthologs of UVRAG and Rubicon, which is part of a Beclin-1-Vps34-containing autophagy complex in mammals (44), have also been identified in T. molitor. Furthermore, orthologs of the PI3P-binding protein Atg18 and its interaction partner Atg2, required for autophagosome formation in yeast, Drosophila and humans, were also identified in T. molitor (Table 3). Additionally, we also identified T. molitor Atg9, a multi-spanning membrane protein supporting the supply of lipid bilayers required for the formation of the autophagosome in yeast and mammalian systems $(45,46)$. Notably, the AMBRA1, Bcl-2 and Bcl-x regulatory genes were not identified in the T. molitor RNA-Seq database. These three genes have also not been identified in the genome of yeast (Table 3 ).

\section{Genes Involved in Vesicle Expansion and Completion in T. molitor}

As detailed earlier, two ubiquitin-like protein complexes (the Atg5-Atg12/Atg16 and Atg8-PE complexes) and four important enzymes, namely the proteolytic enzyme Atg4, the E1-like enzyme Atg7, and the E2-like enzymes Atg3 and Atg10, are required for vesicle expansion and completion. The eight 
TABLE 1 | Up-stream autophagy signaling genes in T. molitor.

\begin{tabular}{|c|c|c|c|c|c|c|c|c|c|c|c|c|}
\hline \multirow[t]{2}{*}{ Generic name } & \multicolumn{3}{|c|}{ Homo sapiens } & \multicolumn{3}{|c|}{ Saccharomyces cerevisiae S288c } & \multicolumn{3}{|c|}{ Drosophila melanogaster } & \multicolumn{3}{|c|}{ Tenebrio molitor } \\
\hline & $\begin{array}{l}\text { Specific } \\
\text { name }\end{array}$ & Accession No. & $\begin{array}{l}\text { Amino } \\
\text { acid } \\
\text { length }\end{array}$ & Specific name & $\begin{array}{l}\text { Accession } \\
\text { No. }\end{array}$ & $\begin{array}{l}\text { Amino } \\
\text { acid } \\
\text { length }\end{array}$ & $\begin{array}{l}\text { Specific } \\
\text { name }\end{array}$ & Accession No. & $\begin{array}{l}\text { AminoAcid } \\
\text { length }\end{array}$ & Specificname & $\begin{array}{l}\text { Amino acid } \\
\text { Lengths } \\
(\mathrm{Tm} / \mathrm{Tc})^{*}\end{array}$ & Source \\
\hline Akt1 & Akt1 & AAL55732.1 & 480 & - & - & - & Akt1 & NP_732114.1 & 530 & Akt1 & $515(F)^{\star \star /} 510$ & $\begin{array}{l}\text { EST, } \\
\text { RNA- } \\
\text { Seq }\end{array}$ \\
\hline $\begin{array}{l}\text { AMP-activated protein } \\
\text { kinase }(A M P K)\end{array}$ & AMPK & AAB32732.1 & 552 & AMPK gamma & P12904.1 & 322 & SNF1A & NP_477313.1 & 582 & AMPK & $526(F)^{\star \star} / 526$ & $\begin{array}{l}\text { EST, } \\
\text { RNA- } \\
\text { Seq }\end{array}$ \\
\hline liver kinase $\mathrm{B} 1$ ( $L K B 1)$ & $\angle K B 1$ & AAB05809.1 & 433 & - & _- & - & $\angle K B 1$ & NP_650302.1 & 567 & $L K B 1$ & $458\left(F^{\star \star} / 443\right.$ & EST \\
\hline $\begin{array}{l}\text { Lethal with Sec Thirteen } \\
8 \text { (Lst8) }\end{array}$ & Lst8 & AAO73410.1 & 260 & Lst8 & NP_014392.3 & 303 & Lst8 & NP_572572.1 & 313 & Lst8 & $309(\mathrm{~F})^{\star \star} / 309$ & $\begin{array}{l}\text { RNA- } \\
\text { Seq }\end{array}$ \\
\hline P53 & p53 & BAC16799.1 & 393 & - & - & - & $p 53$ & NP_001247252.1 & 318 & $p 53$ & $375(F)^{\star \star} / 350$ & EST \\
\hline $\begin{array}{l}\text { Poly-(ADP-ribose) } \\
\text { polymerase (Parp) }\end{array}$ & Parp1 & NP_001609.2 & 1,014 & - & - & - & Parp & NP_001104452.1 & 994 & Parp & $983(P)^{\star \star} / 991$ & $\begin{array}{l}\text { RNA- } \\
\text { Seq }\end{array}$ \\
\hline $\begin{array}{l}\text { Regulatory-associated } \\
\text { protein of mTOR } \\
\text { (Raptor) }\end{array}$ & Raptor & AAM09075.1 & 1,335 & $\begin{array}{l}\text { Mitochondrial DNA } \\
\text { polymerase-encoding } 1 \\
\text { (Mip1p) }\end{array}$ & NP_014975.2 & 1,254 & Raptor & NP_572294.2 & 1,621 & Raptor & $1,273(F)^{\star \star} / 1,264$ & $\begin{array}{l}\text { RNA- } \\
\text { Seq }\end{array}$ \\
\hline $\begin{array}{l}\text { Ras homolog enriched } \\
\text { in brain (Rheb) }\end{array}$ & Rheb & NP_005605.1 & 184 & Rheb1p & NP_009956.2 & 209 & Rheb & NP_730950.2 & 182 & Rheb & $182(F)^{\star \star} / 182$ & $\begin{array}{l}\text { EST, } \\
\text { RNA- } \\
\text { Seq }\end{array}$ \\
\hline $\begin{array}{l}\text { Ribosomal Protein S6 } \\
\text { (RpS6) }\end{array}$ & S6 & NP_001001.2 & 249 & - & - & - & Rps6 & NP_511073.1 & 248 & Rps6 & $248(F)^{\star \star} / 248$ & $\begin{array}{l}\text { EST, } \\
\text { RNA- } \\
\text { Seq }\end{array}$ \\
\hline $\begin{array}{l}\text { Ribosomal protein S6 } \\
\text { kinase (S6k) }\end{array}$ & S6K & NP_003152.1 & 525 & $\begin{array}{l}\text { ribosomal } 40 \text { S subunit } \\
\text { protein } \mathrm{S} 6 \mathrm{~B}\end{array}$ & DAA07295.1 & 236 & $\begin{array}{l}\text { S6k } \\
\text { (CG10539) }\end{array}$ & NP_523941.2 & 490 & S6K & $746(F)^{\star \star} / 738$ & $\begin{array}{l}\text { RNA- } \\
\text { Seq }\end{array}$ \\
\hline $\begin{array}{l}\text { Target of rapamycin } \\
\text { (TOR) }\end{array}$ & $m T O R$ & NP_004949.1 & 2,549 & $\begin{array}{l}\text { Tor1p } \\
\text { Tor2p }\end{array}$ & $\begin{array}{l}\text { NP_012600.1 } \\
\text { NP } 012719.2\end{array}$ & $\begin{array}{l}2,470 \\
2,474\end{array}$ & TOR & NP_001260427.1 & 2,471 & TOR & $2,397(F)^{\star \star} / 2,400$ & $\begin{array}{l}\text { RNA- } \\
\text { Seg }\end{array}$ \\
\hline $\begin{array}{l}\text { Tuberous sclerosis } 1 \\
\text { (TSC1) }\end{array}$ & hamartin & NP_001155898.1 & 1,163 & - & - & - & Tsc1 & NP_477415.1 & 1,100 & TSC1 & $1,056(F)^{\star \star} / 1,047$ & $\begin{array}{l}\text { RNA- } \\
\text { Seq }\end{array}$ \\
\hline $\begin{array}{l}\text { Tuberous sclerosis } 2 \\
\text { (TSC2) }\end{array}$ & TSC2 & AAI50301.1 & 1,784 & - & - & - & gigas & NP_524177.1 & 1,847 & TSC2 & $1,735(F)^{\star \star} / 1,722$ & $\begin{array}{l}\text { RNA- } \\
\text { Seq }\end{array}$ \\
\hline
\end{tabular}

*Amino acid lengths have been predicted based on the length of $T$. molitor (Tm) and T. castaneum genes $(T c)$ genes.

${ }^{* *}(F)$ and $(P)$ indicate full-length open reading frame (ORF) CDNA sequences, respectively.

Genes putatively involved in the generation and processing of the signals that eventually activate the master regulator TOR. Most of them were identified in the T. molitor RNA-Seq database (but only a few in the EST database) using the Drosophila orthologs as a reference. A comparison of the identified genes with their homologs in the unicellular eukaryote S. cerevisiae and the multicellular human (H. sapiens) is given. Blank boxes indicate that no homologs of the respective genes, especially those of S. cerevisiae, were found. 
TABLE 2 | Autophagy-related genes involved in autophagy initiation in T. molitor.

\begin{tabular}{|c|c|c|c|c|c|c|c|c|c|c|c|c|}
\hline \multirow[t]{2}{*}{$\begin{array}{l}\text { Generic } \\
\text { name }\end{array}$} & \multicolumn{3}{|c|}{ Homo sapiens } & \multicolumn{3}{|c|}{$\begin{array}{l}\text { Saccharomyces cerevisiae } \\
\text { S288c }\end{array}$} & \multicolumn{3}{|c|}{ Drosophila melanogaster } & \multicolumn{3}{|c|}{ Tenebrio molitor } \\
\hline & $\begin{array}{l}\text { Specific } \\
\text { name }\end{array}$ & Accession No. & $\begin{array}{c}\text { Amino } \\
\text { Acid } \\
\text { length }\end{array}$ & $\begin{array}{l}\text { Specific } \\
\text { name }\end{array}$ & $\begin{array}{l}\text { Accession } \\
\text { No. }\end{array}$ & $\begin{array}{c}\text { Amino } \\
\text { Acid } \\
\text { length }\end{array}$ & $\begin{array}{l}\text { Specific } \\
\text { name }\end{array}$ & Accession No. & $\begin{array}{c}\text { Amino } \\
\text { Acid } \\
\text { length }\end{array}$ & $\begin{array}{l}\text { Specific } \\
\text { name }\end{array}$ & $\begin{array}{l}\text { Amino } \\
\text { Acid } \\
\text { Lengths } \\
\text { (Tm/Tc)* }\end{array}$ & Source \\
\hline $\begin{array}{l}\text { Autophagy- } \\
\text { specific } \\
\text { gene } 1 \\
\text { (Atg1) }\end{array}$ & $\begin{array}{l}\text { unc-51 like } \\
\text { autophagy } \\
\text { activating } \\
\text { kinase } 1 \\
\text { (ULK1) }\end{array}$ & NP_003556.1 & 1,050 & $\operatorname{Atg} 1 p$ & NP_011335.1 & 897 & $\operatorname{Atg} 1$ & NP_001163433.1 & 855 & Atg1 & $\begin{array}{c}792(\mathrm{~F})^{\star} \\
\star / 779\end{array}$ & $\begin{array}{l}\text { RNA- } \\
\text { Seq }\end{array}$ \\
\hline $\begin{array}{l}\text { Autophagy- } \\
\text { specific } \\
\text { gene } 13 \\
\text { (Atg13) }\end{array}$ & $\operatorname{Atg} 13$ & NP_001192048.1 & 550 & $\operatorname{Atg} 13 p$ & NP_015511.1 & 738 & $\operatorname{Atg} 13$ & NP_649796.1 & 523 & Atg13 & $\begin{array}{c}391(\mathrm{~F})^{\star \star} / \\
399\end{array}$ & $\begin{array}{l}\text { RNA- } \\
\text { Seq }\end{array}$ \\
\hline $\begin{array}{l}\text { Autophagy- } \\
\text { specific } \\
\text { gene } 29 \\
\text { (Atg29) }\end{array}$ & - & - & - & Atg29p & NP_015159.1 & 213 & - & - & - & - & - & - \\
\hline $\begin{array}{l}\text { Autophagy- } \\
\text { specific } \\
\text { gene } 31 \\
\text { (Atg31) }\end{array}$ & - & - & - & Atg31p & NP_010305.1 & 196 & - & - & - & - & - & - \\
\hline $\begin{array}{l}\text { Autophagy- } \\
\text { specific } \\
\text { gene 101 } \\
\text { (Atg101) }\end{array}$ & Atg101 & NP_068753.2 & 218 & - & - & - & CG7053 & NP_573326.1 & 218 & Atg101 & $\begin{array}{c}220(\mathrm{~F})^{\star \star} / \\
220\end{array}$ & $\begin{array}{l}\text { RNA- } \\
\text { Seq }\end{array}$ \\
\hline $\begin{array}{l}\text { FAK family- } \\
\text { interacting } \\
\text { protein of } \\
200 \mathrm{kDa} \\
\text { (Fip200) }\end{array}$ & $\begin{array}{l}\text { RB1- } \\
\text { inducible } \\
\text { coiled-coil } \\
1 \\
\text { (RB1CC1) }\end{array}$ & NP_055596.3 & 1,594 & $\operatorname{Atg} 17 p$ & NP_013527.3 & 417 & CG1347 & NP_649573.2 & 1357 & Fip200 & $\begin{array}{l}1,387 \\
(F)^{\star \star} / \\
1,382\end{array}$ & $\begin{array}{l}\text { RNA- } \\
\text { Seq }\end{array}$ \\
\hline
\end{tabular}

*Amino acid lengths have been predicted based on the length of $T$. molitor (Tm) and T. castaneum genes (TC) genes.

${ }^{* *}(F)$ and $(P)$ indicate full-length ORF cDNA sequences and partial ORF cDNA sequences, respectively.

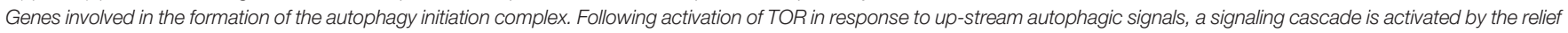


Atg17, Atg29, and Atg31 in yeast or Atg101 and Fip200 in higher eukaryotes, including T. molitor.

corresponding genes were highly conserved in all experimental species, from yeast to humans. Of note, four isotypes of Atg4 genes and two isotypes of the Atg 8 have been identified in humans and Drosophila, respectively. Putative orthologs of the autophagy genes involved in vesicle expansion and completion were identified in the T. molitor RNA-Seq and EST databases, except for the gene encoding Atg10, acting as an E2-like enzyme for the assembly of the Atg5-Atg12/Atg16 complex (Table 4).

\section{AUTOPHAGIC SIGNATURES OF T. MOLITOR IN RESPONSE TO THE INTRACELLULAR BACTERIUM, LISTERIA MONOCYTOGENES}

T. molitor has been exploited as an experimental model for hostpathogen interaction studies, especially those to unravel the intricacies of the insect innate immunity. In the last decade, owing to the availability of whole genome, transcriptome, and EST sequences, researchers in the field were able to explore the intricacies of cellular and humoral immunity against pathogenic infections in this model insect. In particular, elegant biochemical, molecular, and in silico studies allowed to identify the components of the T. molitor Toll and IMD signaling cascades and to propose their role in insect immunity $(47,48)$. The conserved role of both extracellular and intracellular pathwaypathway components have been elucidated through protein induction, gene expression and RNA interference (RNAi)-based gene silencing studies (49-51).

Most significantly, valuable insights into humoral immunity were obtained through the study of the synthesis of antimicrobial peptides (AMPs), hemocyte-driven phagocytosis, and the prophenoloxidase cascade regulating the process of melanization (52). In the context of autophagic control of T. molitor defenses, the RNA-Seq and EST databases have contributed to unravel the mysteries of the autophagy-signaling cascade upon $L$. monocytogenes challenge. Further, in some recent studies, the existence of a cross-talk between autophagy and the NF- $\mathrm{KB}$ controlled IMD pathway upon $L$. monocytogenes challenge in $T$. molitor has been advocated (53); this could help extrapolate general mechanism describing the regulation of host immune strategies 
TABLE 3 | Autophagy-related genes involved in vesicle nucleation in T. molitor.

Homo sapiens

Saccharomyces cerevisiae S288c

Drosophila melanogaster

Tenebrio molitor

\begin{tabular}{|c|c|c|c|c|c|c|c|c|c|c|c|c|}
\hline & Specific name & Accession No. & $\begin{array}{l}\text { Amino } \\
\text { acid } \\
\text { length }\end{array}$ & $\begin{array}{l}\text { Specific } \\
\text { name }\end{array}$ & $\begin{array}{l}\text { Accession } \\
\text { No. }\end{array}$ & $\begin{array}{l}\text { Amino } \\
\text { acid } \\
\text { length }\end{array}$ & Specific name & Accession No. & $\begin{array}{l}\text { Amino } \\
\text { acid } \\
\text { length }\end{array}$ & $\begin{array}{l}\text { Specific } \\
\text { name }\end{array}$ & $\begin{array}{l}\text { Amino acid } \\
\text { lengths } \\
(\mathrm{Tm} / \mathrm{Tc})^{\star}\end{array}$ & Source \\
\hline $\begin{array}{l}\text { Activating molecule in Beclin1- } \\
\text { regulated autophagy (AMBRA1) }\end{array}$ & AMBRA1 & $\mathrm{ABI} 74670.1$ & 1,269 & - & - & - & - & - & - & - & - & - \\
\hline Autophagy-specific gene 2 & Atg2a & NP_055919.2 & 1,938 & $\operatorname{Atg} 2 p$ & NP_014157.1 & 1,592 & $\operatorname{Atg} 2$ & NP_647748.1 & 1906 & Atg2 & $1,945(\mathrm{P})^{\star \star \star /}$ & RNA- \\
\hline (Atg2) & $A \operatorname{tg} 2 b$ & NP_060506.5 & 2,078 & & & & & & & & 2,040 & Seq \\
\hline $\begin{array}{l}\text { Autophagy-specific gene } 6 \\
\text { (Atg6) }\end{array}$ & $\begin{array}{l}\text { Bcl-2 interacting coiled- } \\
\text { coil protein (Beclin1) }\end{array}$ & AAD27650.1 & 450 & Vps30p & NP_015205.1 & 557 & Atg6 & NP_651209.1 & 422 & Atg 6 & $\begin{array}{c}386(F)^{\star \star \star} / \\
396\end{array}$ & $\begin{array}{l}\text { RNA- } \\
\text { Seq }\end{array}$ \\
\hline Autophagy-specific gene 9 & Atg9a & NP_001070666.1 & 839 & Atg9p & NP_010132.1 & 997 & $\operatorname{Atg} 9$ & NP_001261023.1 & 852 & Atg9 & $718(\mathrm{~F})^{\star \star \star /}$ & RNA- \\
\hline (Atg9) & Atg9b & NP_775952.4 & 924 & & & & & & & & 662 & Seq \\
\hline $\begin{array}{l}\text { Autophagy-specific gene } 14 \\
\text { (Atg14) }\end{array}$ & $\operatorname{Atg} 14$ & NP_055739.2 & 492 & $\operatorname{Atg} 14 p$ & NP_009686.1 & 344 & CG11877 & NP_651669.1 & 503 & $\operatorname{Atg} 14$ & $\begin{array}{l}472(\mathrm{~F})^{\star \star \star} / \\
478(\mathrm{Bt})^{\star \star}\end{array}$ & $\begin{array}{l}\text { RNA- } \\
\text { Seq }\end{array}$ \\
\hline $\begin{array}{l}\text { Autophagy-specific gene } 18 \\
\text { (Atg18) }\end{array}$ & $\begin{array}{l}\text { WD repeat domain, } \\
\text { Phosphoinositide } \\
\text { interacting } 1 \text { (WIP/1) }\end{array}$ & NP_060453.3 & 446 & $\operatorname{Atg} 18 p$ & NP_444297.1 & 500 & Atg18 & NP_648184.1 & 377 & $\operatorname{Atg} 18$ & $\begin{array}{c}406\left(F^{\star \star \star} /\right. \\
409\end{array}$ & $\begin{array}{l}\text { RNA- } \\
\text { Seq }\end{array}$ \\
\hline $\begin{array}{l}\text { B-cell leukemia/ lymphoma-2- } \\
\text { alpha protein (Bcl-2) }\end{array}$ & $B C l-2$ & ABX60202.1 & 239 & - & - & - & Debcl & NP_788278.1 & 300 & - & - & - \\
\hline$B C l-x$ & $B C l-x$ & AAB17354.1 & 227 & - & - & - & - & - & - & - & - & - \\
\hline $\begin{array}{l}\text { Run domain Beclin-1- } \\
\text { interacting and cystein-rich } \\
\text { containing protein (Rubicon) }\end{array}$ & KIAA0226 & NP_001139114.1 & 927 & - & - & - & - & - & - & Rubicon & $\begin{array}{l}880\left(F^{\star \star \star} /\right. \\
884\end{array}$ & EST \\
\hline $\begin{array}{l}\text { UV-resistance associated gene } \\
\text { (Uvrag) }\end{array}$ & UVRAG & BAA90829.1 & 699 & - & - & - & Uvrag & NP_609632.1 & 696 & UVRAG & $\begin{array}{l}729\left(\mathrm{~F}^{\star \star \star /}\right. \\
716\end{array}$ & $\begin{array}{l}\text { RNA- } \\
\text { Seq }\end{array}$ \\
\hline $\begin{array}{l}\text { Phosphoinositide 3-kinase } \\
\text { regulatory subunit } 4 \text { (PIK3R4) }\end{array}$ & PIK3R4 & NP_055417.1 & 1,358 & $\begin{array}{l}\text { Vacuolar } \\
\text { protein sorting } \\
15 \text { (VPS15p) }\end{array}$ & NP_009655.2 & 1,454 & $\begin{array}{l}\text { Immune response } \\
\text { Deficient } 1 \text { (ird1) }\end{array}$ & NP_649868.1 & 1342 & VPS15 & $\begin{array}{l}1,337\left(\mathrm{~F}^{\star \star \star} /\right. \\
1,330\end{array}$ & $\begin{array}{l}\text { RNA- } \\
\text { Seq }\end{array}$ \\
\hline $\begin{array}{l}\text { Phosphotidyl-inositol } 3 \text { kinase } \\
\text { (PI3K) }\end{array}$ & РІКЗСЗ & NP_002638.2 & 887 & $\begin{array}{l}\text { Vacuolar } \\
\text { protein sorting } \\
34 \text { (VPS34p) }\end{array}$ & NP_013341.1 & 875 & $\begin{array}{l}\text { Phosphatidyl- } \\
\text { inositol } 3 \text { kinase } \\
\text { 59F (Pi3K59F) }\end{array}$ & NP_477133.1 & 949 & VPS34 & $\begin{array}{l}1,700(P)^{\star \star \star /} \\
2,070\end{array}$ & $\begin{array}{l}\text { RNA- } \\
\text { Seq }\end{array}$ \\
\hline
\end{tabular}

*Amino acid lengths have been predicted based on the length of $T$. molitor $(T m)$ and $T$. castaneum genes $(T c)$ genes.

${ }^{*}$ Bt; Amino acid lengths based on Bombus terrestris gene.

***(F) and (P) indicate full-length ORF CDNA sequences and partial ORF CDNA sequences

This step involves the recruitment of Atg proteins to the phagophore assembly site (PAS) in yeast or its equivalents in higher animals. Various Atg proteins taking part in this process were identified in the RNA-Seq database. 
TABLE 4 | Autophagy related genes involved in elongation and completion in T. molitor.

\begin{tabular}{|c|c|c|c|c|c|c|c|c|c|c|c|c|}
\hline \multirow[t]{2}{*}{$\begin{array}{l}\text { Generic } \\
\text { name }\end{array}$} & \multicolumn{3}{|c|}{ Homo sapiens } & \multicolumn{3}{|c|}{$\begin{array}{c}\text { Saccharomyces cerevisiae } \\
\text { S288c }\end{array}$} & \multicolumn{3}{|c|}{ Drosophila melanogaster } & \multicolumn{3}{|c|}{ Tenebrio molitor } \\
\hline & $\begin{array}{l}\text { Specific } \\
\text { Name }\end{array}$ & Accession No. & $\begin{array}{l}\text { Amino } \\
\text { acid } \\
\text { length }\end{array}$ & $\begin{array}{c}\text { Specific } \\
\text { name }\end{array}$ & $\begin{array}{l}\text { Accession } \\
\text { No. }\end{array}$ & $\begin{array}{l}\text { Amino } \\
\text { acid } \\
\text { length }\end{array}$ & $\begin{array}{l}\text { Specific } \\
\text { name }\end{array}$ & Accession No. & $\begin{array}{l}\text { Amino } \\
\text { acid } \\
\text { length }\end{array}$ & $\begin{array}{l}\text { Specific } \\
\text { name }\end{array}$ & $\begin{array}{l}\text { Amino } \\
\text { acid } \\
\text { lengths } \\
(\mathrm{Tm} / \mathrm{Tc})^{\star}\end{array}$ & Source \\
\hline $\begin{array}{l}\text { Autophagy- } \\
\text { specific } \\
\text { gene } 3 \\
\text { (Atg3) }\end{array}$ & $\operatorname{Atg} 3$ & NP_071933.2 & 314 & $\operatorname{Atg} 3 p$ & NP_014404.3 & 310 & Aut1 & NP_649059.1 & 330 & $\operatorname{Atg} 3$ & $\begin{array}{l}320\left(F^{\star \star \star} /\right. \\
316\end{array}$ & $\begin{array}{l}\text { EST, } \\
\text { RNA- } \\
\text { Seq }\end{array}$ \\
\hline $\begin{array}{l}\text { Autophagy- } \\
\text { specific } \\
\text { gene } 4 \\
\text { (Atg4) }\end{array}$ & $\begin{array}{l}\text { Atg } 4 a \\
\text { Atg } 4 b \\
\text { Atg } 4 c \\
\text { Atg } 4 d\end{array}$ & $\begin{array}{l}\text { AAH61696.1 } \\
\text { EAW71278.1 } \\
\text { EAX06579.1 } \\
\text { AAH68992.1 }\end{array}$ & $\begin{array}{l}398 \\
415 \\
458 \\
474\end{array}$ & $\operatorname{Atg} 4 p$ & NP_014176.2 & 494 & $\operatorname{Atg} 4$ & NP_608563.1 & 411 & $\operatorname{Atg} 4$ & $\begin{array}{c}369(F)^{\star \star \star} / \\
366\end{array}$ & $\begin{array}{l}\text { RNA- } \\
\text { Seq }\end{array}$ \\
\hline $\begin{array}{l}\text { Autophagy- } \\
\text { specific } \\
\text { gene } 5 \\
\text { (Atg5) }\end{array}$ & $\operatorname{Atg} 5$ & AGC52703.1 & 275 & Atg5p & NP_015176.1 & 294 & $\operatorname{Atg} 5$ & NP_572390.1 & 269 & $\operatorname{Atg} 5$ & $\begin{array}{c}263(F)^{\star \star \star \star} / \\
263\end{array}$ & $\begin{array}{l}\text { RNA- } \\
\text { Seq }\end{array}$ \\
\hline $\begin{array}{l}\text { Autophagy- } \\
\text { specific } \\
\text { gene } 8 \\
\text { (Atg8) }\end{array}$ & $\begin{array}{l}\text { microtubule- } \\
\text { associated } \\
\text { protein } 1 \text { light } \\
\text { chain } 3 \text { alpha } \\
\text { (MAP1LC3A) }\end{array}$ & NP_852610.1 & 125 & Atg $8 p$ & NP_009475.1 & 117 & $\begin{array}{l}\text { Atg8a } \\
\text { Atg8b }\end{array}$ & $\begin{array}{l}\text { NP_727447.1 } \\
\text { NP_650649.1 }\end{array}$ & $\begin{array}{l}121 \\
120\end{array}$ & $\operatorname{Atg} 8$ & $\begin{array}{c}120\left(F^{\star \star \star} /\right. \\
120\end{array}$ & $\begin{array}{l}\text { RNA- } \\
\text { Seq }\end{array}$ \\
\hline $\begin{array}{l}\text { Autophagy- } \\
\text { specific } \\
\text { gene } 10 \\
\text { (Atg10) }\end{array}$ & ATG10 & NP_001124500.1 & 220 & $\operatorname{Atg} 10 p$ & NP_013058.1 & 167 & CG12821 & NP_001097216.1 & 212 & - & - & - \\
\hline $\begin{array}{l}\text { Autophagy- } \\
\text { specific } \\
\text { gene } 12 \\
\text { (Atg12) }\end{array}$ & $\operatorname{Atg} 12$ & ACD74941.1 & 187 & $\operatorname{Atg} 12 p$ & NP_009776.1 & 186 & Atg12 & NP_648551.3 & 111 & $\operatorname{Atg} 12$ & $\begin{array}{c}129(F)^{\star \star \star} / \\
124\end{array}$ & $\begin{array}{l}\text { RNA- } \\
\text { Seq }\end{array}$ \\
\hline
\end{tabular}

*Amino acid lengths have been predicted based on the length of T. molitor (Tm) and T. castaneum (TC) genes.

${ }^{* *} B t$; amino acid lengths predicted based on the lengths of Bombus terrestris (Bt) gene.

${ }^{* * *}(F)$ and $(P)$ indicate full-length ORF CDNA sequences and partial ORF CDNA sequences, respectively.

against pathogenic microorganisms. In the next paragraphs, we review the components of the conserved autophagy signaling cascade in T. molitor and show that they are functionally required to counteract the pathogenicity of $L$. monocytogenes. We not only lay emphasis on the role of Atgs in beetle immunity, with special reference to autophagy-based clearance of Listeria in the T. molitor model, but also delineate reasonable hypotheses on the extent of the cross-talk between autophagy and the IMD pathway.

In separate studies, we have functionally characterized TOR (54), the HORMA-domain-containing protein Atg13 (55), Atg6 (Beclin-1 in humans) (56), Atg3/Atg5 (42), and Atg8 [microtubule-associated protein 1 light chain 3 alpha (MAPILC3A) in humans] (57) in the T. molitor model. The corresponding genes have been listed together with other $T$. molitor Atgs in Table 5 and have been categorized, due to their conserved functions, as upstream autophagy signaling genes (TmTOR), autophagy-related genes involved in autophagy initiation (TmAtg13), autophagy-related genes for vesicle nucleation (TmAtg6), and autophagy-related genes for elongation and completion of autophagosome formation (TmAtg3, TmAtg5, and TmAtg8). Specifically, the autophagy machinery of $T$. molitor has been functionally dissected in the process of $L$. monocytogenes clearance or suppression by the host. Notably, L. monocytogenes, a facultative gram-positive bacterium, has been used for the study of host-pathogen interactions in both vertebrates and invertebrates (58).

In Drosophila, the autophagy machinery is stimulated after recognition of L. monocytogenes invasion by PGRP-LE, whereas transcription factors downstream of the NF- $\kappa \mathrm{B}$ pathway (Relish, Dif, and Dorsal) and Atg5 are not required for PGRP-LEdependent suppression of L. monocytogenes growth (59). Similar to the Drosophila model, the requirement of TmPGRPLE for defense of T. molitor against L. monocytogenes infection was established using a gene silencing assay (60). In fact, 
TABLE 5 | Summary of the autophagic signatures functionally characterized in T. molitor implicated in autophagy-mediated clearance of the gram-positive bacterium L. monocytogenes.

\begin{tabular}{|c|c|c|c|c|c|c|}
\hline \multirow{2}{*}{$\begin{array}{l}\text { Autophagy } \\
\text { genes }\end{array}$} & \multirow{2}{*}{$\begin{array}{l}\text { Autophagy } \\
\text { functional } \\
\text { category }\end{array}$} & \multicolumn{3}{|r|}{ Nucleotide and protein features } & \multirow{2}{*}{$\begin{array}{l}\text { Role in autophagy in } \\
\text { relation to } L \text {. monocy- } \\
\text { togenes infection }\end{array}$} & \multirow[t]{2}{*}{ Reference } \\
\hline & & $\begin{array}{l}\text { Nucleotide } \\
\text { length } \\
\text { (ORF) }\end{array}$ & $\begin{array}{l}\text { Protein } \\
\text { length }\end{array}$ & Domain analysis & & \\
\hline Atg3 & $\begin{array}{l}\text { Elongation and } \\
\text { completion of } \\
\text { autophagosome } \\
\text { formation }\end{array}$ & $963 \mathrm{bp}$ & 320 aa & $\begin{array}{l}\text { N-terminal domain, catalytic (autophagy-related protein 3) domain } \\
\text { and C-terminal domain }\end{array}$ & $\begin{array}{l}\text { Putative role in mediating } \\
\text { autophagy-based } \\
\text { clearance of Listeria in } \\
\text { the } T \text {. molitor model }\end{array}$ & $(42)$ \\
\hline Atg5 & $\begin{array}{l}\text { Elongation and } \\
\text { completion of } \\
\text { autophagosome } \\
\text { formation }\end{array}$ & 792 bp & 263 aa & Autophagy-related protein 5 domain & $\begin{array}{l}\text { Putative role in mediating } \\
\text { autophagy-based } \\
\text { clearance of Listeria in } \\
\text { the } T \text {. molitor model }\end{array}$ & $(42)$ \\
\hline $\operatorname{Atg} 13$ & $\begin{array}{l}\text { Initiation (ULK1 } \\
\text { complex) }\end{array}$ & $1,176 \mathrm{bp}$ & 391 aa & $\begin{array}{l}\text { N-terminal Atg13 domain with a HORMA (Hop1, Rev7 and Mad2 } \\
\text { fold) }\end{array}$ & Not studied & (55) \\
\hline $\begin{array}{l}\text { Atg8 (Atg8- } \\
\text { II/PE } \\
\text { complex) }\end{array}$ & $\begin{array}{l}\text { Elongation and } \\
\text { completion of } \\
\text { autophagosome } \\
\text { formation }\end{array}$ & $363 \mathrm{bp}$ & 120 aa & Microtubule-associated proteins 1a/1b light chain B-related domain & $\begin{array}{l}\text { Putative role in } \\
\text { autophagy-based } \\
\text { clearance of Listeria in } T \text {. } \\
\text { molitor }\end{array}$ & $(57)$ \\
\hline $\begin{array}{l}\text { Target of } \\
\text { rapamycin } \\
(T O R)\end{array}$ & $\begin{array}{l}\text { Upstream } \\
\text { signaling genes }\end{array}$ & $7,197 \mathrm{bp}$ & $\begin{array}{l}2,398 \\
\text { aa }\end{array}$ & $\begin{array}{l}\text { Huntington domain, EF3A, ATM, TOR (HEAT) repeat, and focal } \\
\text { adhesion kinase targeting (FAT), rapamycin binding, } \\
\text { phosphatidylinositol 3-/4-kinase, and FRAP, ATM and TRRAP C- } \\
\text { terminal (FATC) domains }\end{array}$ & $\begin{array}{l}\text { Negative correlation with } \\
\text { autolysosome formation } \\
\text { after bacterial challenge }\end{array}$ & $(54)$ \\
\hline Atg6 & $\begin{array}{l}\text { Nucleation (class } \\
\text { III PI(3)K complex) }\end{array}$ & $1,161 \mathrm{bp}$ & 386 aa & Atg6 domain & $\begin{array}{l}\text { Putative role in } \\
\text { autophagy-based } \\
\text { clearance of Listeria in } T \text {. } \\
\text { molitor }\end{array}$ & (56) \\
\hline
\end{tabular}

*A cross-talk mechanism between the IMD and autophagy pathways is established as TmRelish, a transcription factor of the IMD pathway is implicated not only in the regulation of AMP genes but also in the induction of autophagy genes in response to L. monocytogenes challenge. In fact, TmAtg1 was downregulated both in hemocytes and fat body upon TmRelish knockdown

knockdown of TmPGRP-LE followed by L. monocytogenes challenge led to a marked reduction in the survival of $T$. molitor larvae, thereby clearly indicating that TmPGRP-LE is a fundamental component of the pathogen recognition system, which could modulate the downstream NF- $\kappa \mathrm{B}$ signaling cascade or the autophagic machinery to eliminate or suppress the pathogenicity of microorganisms.

Although it is logical to assume that the L. monocytogenesinduced autophagy is independent of the IMD pathway in Drosophila, the existence of a cross-talk between autophagy and the IMD pathway seems more of a reasonable hypothesis. In this regard, we have observed that knocking down TmRelish, encoding a transcription factor downstream of the PGRP-LE/ IMD pathway, could directly or indirectly influence the expression of AMP and Atg genes after L. monocytogenes challenge in the fat body and hemocytes of $T$. molitor larvae (Figure 4). Ultimately, L. monocytogenes infection led to reduced survival of TmRelish-knockdown T. molitor larvae. While assessing the expression of Atg genes, it was found that the mRNA levels of $\operatorname{TmAtg} 1$ were significantly decreased in the fat body and hemocytes of T. molitor larvae after L. monocytogenes infection (53). Atg1/ULK-1 is related to autophagy initiation, and its increased expression level is necessary to initiate an appropriate autophagic response in Drosophila and Bombyx mori $(22,61)$. Furthermore, the formation of the Atg1/Atg13 complex leads to the nucleation of the autophagosome membrane, thereby possibly promoting autophagy. Although
Drosophila Atg13 has been reported to enhance both the proautophagic activity of Atg1 and the inhibition of TOR signaling, the role of Atg13 in the molecular mechanisms underlying autophagy initiation in other insects has been studied to a lesser extent. For instance in Bombyx mori, Atg13 (BmAtg13) knockdown and overexpression have been implicated in autophagy inhibition (62). In fact, overexpression of BmAtg13 gene promotes the replication and proliferation of $B$. mori nucleopolyhedrovirus $(B m \mathrm{NPV})$ and silencing results in suppression of BmNPV replication (63). TmAtg13 is implicated in the survival of the host to both Escherichia coli and Staphylococcus aureus infection, since TmAtg13-silenced larvae exhibited reduced survival under microorganism challenge (55).

Atg8/MAP1LC3A is a ubiquitin-like protein controlling the expansion of the phagophore during autophagosome formation. Moreover, it is a reliable marker of autophagosome formation, and its expression during autophagy has been studied in various insect species. In Galleria mellonella, increased activity of Atg8 in parallel to autophagosome formation has been associated with the perivisceral fat body remodeling (64). The Atg8/LC3 positive hemocytes in G. mellonella 24 and 48 hours post-infection with entomopathogenic fungus, Conidiobolus coronatus also relate to autophagosome formation and autophagy (65). Further, in the hematophagous insect Rhodnius prolixus, silencing of Atg8 transcripts led to disrupted lipophagy (sequestration of lipid droplets and degradation of triacylglycerol generating free fattyacids for $\beta$-oxidation) (66). In Drosophila, elevation of Atg8-II 


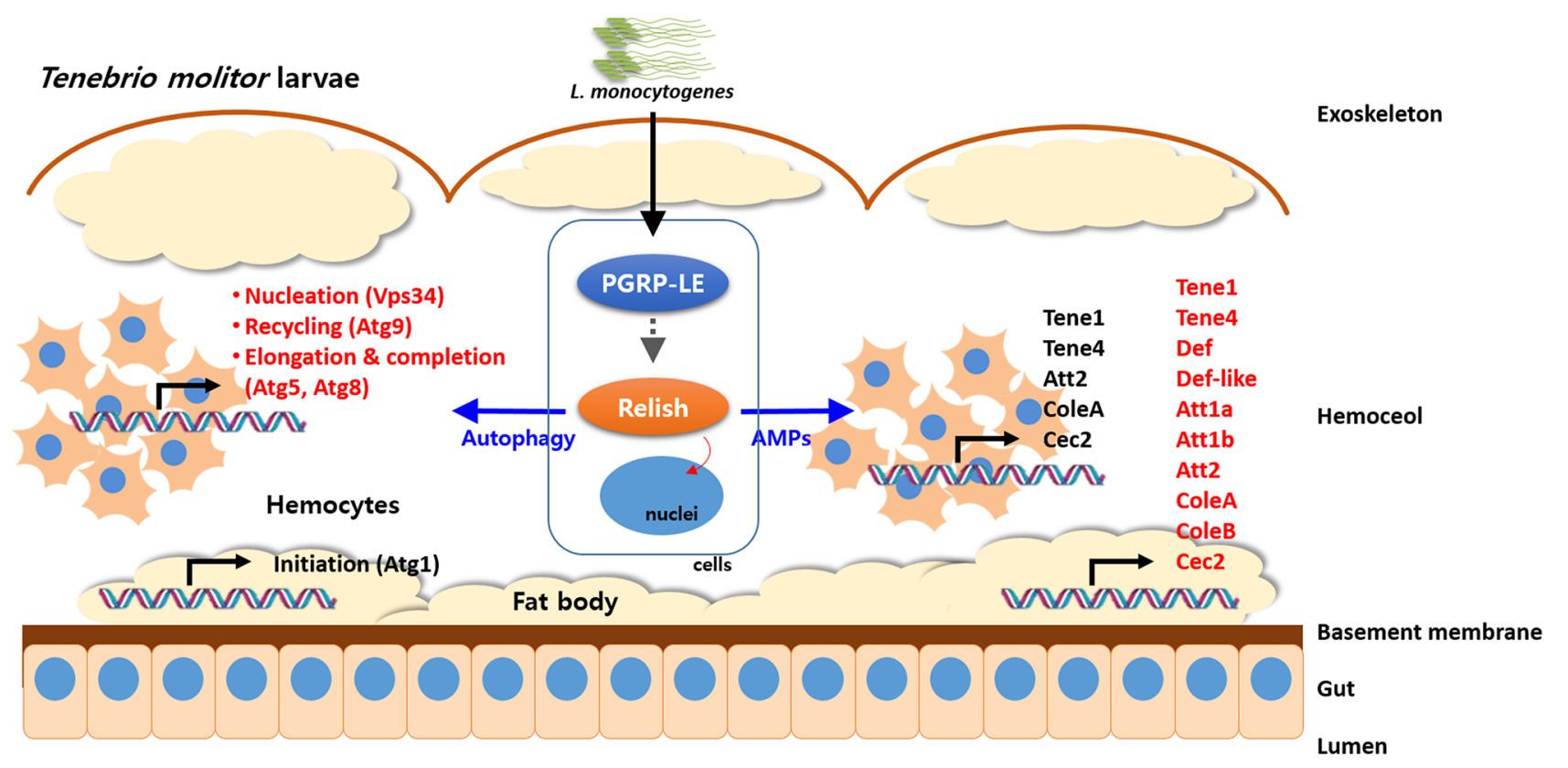

FIGURE 4 | Schematic illustration depicting cross-talk of autophagy process and NF- $\mathrm{kB}$ (Relish) pathway in response to pathogens in T. molitor. The intracellular Gram-positive bacterium, Listeria monocytogenes is recognized by PGRP-LE and the signaling cascade activates the NF- $\kappa B$ transcription factor, Relish. Subsequently, Relish regulates activation of autophagy by direct or indirect stimulation of nucleation step in hemocytes and AMP production in fat body. In addition, the Atg genes related to the nucleation (TmVPS34), recycling (TmAtg9), and elongation and recycling (TmAtg5 and TmAtg8) were significantly regulated by silencing of TmRelish in hemocytes.

level and accumulation of Atg8 in the autophagic punctae have been demonstrated after infection with VSV, RVFV or Zika virus as evidenced through silencing experiments $(67,68)$. In Laodelphax striatellus, Atg8 facilitates Rice stripe virus (RSV) infection in an autophagy-independent manner (69). The higher mortality rates in Aedes albopictus mosquitoes after bloodfeeding of microorganisms and not systemic challenge in Atg8silenced hosts suggest modulation of autophagy in gut immunity (70). The role of the Atg8 homolog of T. molitor (TmAtg8) in mediating autophagy-based clearance of $L$. monocytogenes has been demonstrated through dsRNA-induced gene silencing and recombinant protein expression analysis. Furthermore, the expression levels of TmAtg8 in hemocytes were also found to be markedly reduced after $L$. monocytogenes infection. In contrast, the increasing expression level of autophagy genes with time in L. monocytogenes-infected larvae injected with dsEGFP (negative control for RNAi) suggested autophagic control of L. monocytogenes clearance (57). Another member of the Atg8 family, the microtubule-associated proteins $1 \mathrm{~A} / 1 \mathrm{~B}$ light chain 3C-like protein (TmLc3), exhibiting low amino acid identity (34\%) to TmAtg8 has been characterized in T. molitor; however, its exact role in autophagy-based immunity is yet to be deciphered. Moreover, TmAtg8 protein expression failed to be induced in hemocytes of TmAtg5- knockdown larvae, suggesting a coordinated functional role of elongation and completion of autophagosome assembly for the clearance of L. monocytogenes in the host. Consistently, RNAi-mediated loss of function of
TmAtg5 led to impaired formation of the Atg12-Atg5-Atg16 complex, which facilitates the lipidation of Atg8, that is, the conversion of Atg8-I to Atg8-II, to form the Atg8-PE complex. Further, the lack of induction of the autophagy marker TmAtg8II in the fat body tissues of T. molitor following L. monocytogenes infection is interesting and warrants detailed studies for understanding the mechanism of preferential establishment of autophagy in certain tissues following L. monocytogenes challenge. Certainly, the increase in Atg8 (Atg8-II) signals overtime after exposure to L. monocytogenes infection is indicative of an increasing autophagic control in the host. The involvement of Atg8 in Leishmania parasite survival while infecting macrophages in vitro suggests regulatory control of autophagy by autophagosome formation (71).

In another study, the requirement of TmAtg3 and TmAtg5 for the autophagic control of Listeria infection was thoroughly investigated. RNAi-mediated silencing of TmAtg3 and TmAtg5 led to an increased susceptibility of $T$. molitor larvae to $L$. monocytogenes infection, further confirming the requirement of Atg3 and Atg5 for Atg8 lipidation, formation of the Atg8-PE complex, and subsequent activation of autophagic clearance of microorganisms (42). While TmAtg3 is an E2 ubiquitin-like enzyme responsible for covalent binding of $\mathrm{PE}$ to the $\mathrm{C}$-terminus of Atg8, Atg5 is part of the Atg12-Atg5-Atg16 complex, which regulates the formation of the Atg8-PE complex. Downregulation of Atg8 transcript also downregulating Atg3 expression in insects is suggestive of an interconnection between the two genes (72). 
TmAtg6 (Beclin-1 in mammals), involved in the vesicle nucleation step of the autophagy pathway, has also been found to be required to protect $T$. molitor larvae against $L$. monocytogenes challenge (56). Although Atg6 is a multifunctional protein involved in sorting of vacuolar contents, pollen germination, and tumor suppression, its role in autophagy is highly conserved. In the autophagic pathway, Atg6 forms a complex with Vps34, Vps15, UVRAG, and Vps38 to generate the phagophore. Hence, Atg6 supports autophagymediated immune responses against $L$. monocytogenes.

\section{SUMMARY STATEMENT}

Genes involved in the canonical TOR-regulated autophagy pathway, which were reviewed here, can be conveniently divided into categories depending on their presumed location along the pathway. Upstream regulatory genes in the T. molitor autophagy pathway include the master- regulator TOR and at least seven genes, namely, Akt1, Lkb1, p53, Parp, RpS6, Tsc1, and $T s c 2$, that appear to be absent in the yeast genome are conserved in higher eukaryotes such as Drosophila and humans. Most of these genes have been reported to be active regulators of autophagy induction and tumor suppressors in model organisms. Similarly, the gene sets required for the formation of the autophagy initiation complex (Atg1 kinase complex) after successful induction vary between yeast and higher eukaryotes. For instance, the absence of Atg17 and its interacting proteins Atg29 and Atg31 in higher eukaryotes including T. molitor highlights the discrepancy in the identity of the core components of the autophagy initiation complex. Indeed, in higher eukaryotes Atg17 seems to have been mechanistically replaced by a non-homologous functional equivalent, Fip200 (73). Adding to this complexity, the protein Atg101, absent in yeast interacts with both Atg1 and Fip200 to form the Atg1kinase complex in higher eukaryotes.

The variation in the composition and function of the core autophagy machinery between yeast and higher eukaryotes discussed above highlights the fact that, although genetic screening in $S$. cerevisiae laid the foundation for the molecular understanding of autophagy, fundamental differences in active components and processes exist between yeast and higher eukaryotes. Indeed, the autophagy core machinery of higher eukaryotes has been extensively modified, partly to satisfy the fundamental need to account for the greater genetic diversity and complexity of higher eukaryotes with respect to those of unicellular eukaryotes. Such difference is substantiated by the presence of multiple isoforms of certain Atg genes, including Atg4, Atg8, Atg2, and Atg9 in higher eukaryotes, although no evidence of this rare phenomenon in $S$. cerevisiae was found in T. molitor (74).

\section{FUTURE PERSPECTIVES}

The early discovery of Atg8 lipidation in the 1990s prompted researchers to focus on the mechanisms and functional roles of autophagy-related proteins; in addition, recent studies have raised considerable interest in a wide range of research directions to dissect the autophagy pathway. Current findings on the autophagy pathway in insect model systems derived from various fields such as developmental biology, immunology, epidemiology, and molecular biology, have improved our understanding of the fundamental framework of the autophagy process. In particular, the T. molitor Atg genes have been largely identified, and the functional roles of these signaling components have been demonstrated through gene silencing studies. However, many unanswered questions on the importance of autophagy in metamorphosis and starvation of T. molitor, as well as the role of the interaction between Atg proteins and membrane lipids remains to be answered. Importantly, recent studies in T. molitor and Drosophila have revealed the regulation of Atg genes through NF- $\mathrm{KB}$ factors, suggesting a possible connection between different pathways of immune response, including the IMD pathway and autophagy. In Drosophila, while the activation of autophagy by the plasma membrane receptor Toll-7 is independent of NF- $\mathrm{KB}$ response during VSV infection, the autophagic response to Zika virus infection is NF$\kappa \mathrm{B}$-dependent $(67,68,75)$. Despite the significance of altered NF$\kappa B$ expression at the transcriptional level, the levels of the corresponding protein level seems to be critical in T. molitor. Further, it would be interesting to note the levels of conservation in the transcription factors inhibiting autophagy induction such as Hox-family of proteins in Drosophila and the zinc finger with a SCAN and KRAB domain 3 (ZKSCAN3) in humans. With transcriptome signatures of pathogenic responses in the host readily available in the research domain, a high-throughput unraveling of Atg genes and its regulatory roles in autophagy would become a reality. In fact, the transcriptome of $A n$. aquasalis midgut epithelium is implicated to trigger an autophagic response to Plasmodium vivax invasion (76). In conclusion, the fascinating results obtained from previous studies on T. molitor autophagy has established promising future directions for newcomers and experts in this field of research.

\section{AUTHOR CONTRIBUTIONS}

YJ and YH: Design manuscript concepts. YJ and JL: wrote the draft manuscript. YJ, BP, MK, and YH: Wrote the manuscript. $\mathrm{YH}$ and YL: revised the manuscript. All authors contributed to the article and approved the submitted version.

\section{FUNDING}

This research was supported by Korea Institute of Planning and Evaluation for Technology in Food, Agriculture, Forestry and Fisheries (IPET) through Export Promotion Technology Development Program (Grant no. 617077-5), funded by Ministry of Agriculture, Food, and Rural Affairs (MAFRA). 


\section{REFERENCES}

1. Lee J, Giordano S, Zhang J. Autophagy, Mitochondria and Oxidative Stress: Cross-Talk and Redox Signaling. Biochem J (2012) 441(2):523-40. doi: 10.1042/BJ20111451

2. Fouillet A, Levet C, Virgone A, Robin M, Dourlen P, Reiusset J, et al. ER Stress Inhibites Neuronal Death by Promoting Autophagy. Autophagy (2012) 8 (6):915-26. doi: 10.4161/auto.19716

3. Decuypere J, Parys JB, Bultynck G. Regulation of the Autophagic bcl-2/beclin 1 Interaction. Cells (2012) 1(3):284-312. doi: 10.3390/cells1030284

4. Peracchio C, Alabiso O, Valente G, Isidoro C. Involvement of Autophagy in Ovarian Cancer: A Working Hypothesis. J Ovarian Res (2012) 5(1):22. doi: 10.1186/1757-2215-5-22

5. Li WW, Li J, Bao JK. Microautophagy: Lesser-Known Self-Eating. Cell Mol Life Sci (2012) 69(7):1125-36. doi: 10.1007/s00018-011-0865-5

6. Feng Y, He D, Yao Z, Klionsky DJ. The Machinery of Macroautophagy. Cell Res (2014) 24(1):24-41. doi: 10.1038/cr.2013.168

7. Ohashi Y, Munro S. Membrane Delivery to the Yeast Autophagosome From the Golgi-endosomal System. Mol Biol Cell (2010) 21(22):3998-4008. doi: 10.1091/mbc.e10-05-0457

8. Abounit K, Scarabelli TM, McCauley RB. Autophagy in Mammalian Cells. World J Biol Chem (2012) 3(1):1-6. doi: 10.4331/wjbc.v3.i1.1

9. Polson HEJ, de Lartigue J, Rigden DJ, Reedijk M, Urbe S, Clague MJ, et al. Mammalian Atg18 (WIPI2) Localizes to Omegasome-Anchored Phagophores and Positively Regulated LC3lipidation. Autophagy (2012) 6 (4):506-22. doi: 10.4161/auto.6.4.11863

10. Zhang Y, Sun H, Pei R, Mao B, Zhao Z, Li H, et al. The SARS-CoV2 Protein ORF3a Inhibits Fusion of Autophagosomes With Lysosomes. Cell Discovery (2021) 7(1):31. doi: 10.1038/s41421-021-00268-z

11. Shelly S, Lukinova N, Bambina S, Berman A, Cherry S. Autophagy is an Essential Component of Drosophila Immunity Against Vesicular Stomatitis Virus. Immunity (2009) 30(4):588-98. doi: 10.1016/j.immuni.2009.02.009

12. Echavarria-Consuegra L, Smit JM, Reggiori F. Role of Autophagy During the Replication and Pathogenesis of Common Mosquito-Borne Flavi- and Alphaviruses. Open Biol (2019) 9:190009. doi: 10.1098/rsob.190009

13. Brackney DE, Correa MA, Cozens DW. The Impact of Autophagy on Arbovirus Infection of Mosquito Cells. PloS Neg Trop Dis (2020) 14(5): e0007754. doi: 10.1371/journal.pntd.0007754

14. Kaushik S, Bandyopadhyay U, Sridhar S, Kiffin R, Martinez-Vicente M, Kon M, et al. Chaperone-Mediated Autophagy At a Glance. J Cell Sci (2011) 124(Pt 4):495-9. doi: 10.1242/jcs.073874

15. Levine B, Abrams J. P53: The Janus of Autophagy? Nat Cell Biol (2008) 10 (6):637-9. doi: 10.1038/ncb0608-637

16. Zirin J, Perrimon N. Drosophila as a Model System to Study Autophagy. Semin Immunopathol (2010) 32(4):363-72. doi: 10.1007/s00281-010-0223-y

17. Mizushima N. The Role of the Atg1/ULK1 Complex in Autophagy Regulation. Curr Opin Cell Biol (2010) 22(2):132-9. doi: 10.1016/j.ceb.2009.12.004

18. Kawamata T, Kamada Y, Suzuki K, Kuboshima N, Akimatsu H, Ota S, et al. Characterization of a Novel Autophagy-Specific Gene, ATG29. Biochem Biophys Res Commun (2005) 338(4):1884-9. doi: 10.1016/j.bbrc.2005.10.163

19. Kawamata T, Kamada Y, Kabeya Y, Sekito T, Ohsumi Y. Organization of the Pre-Autophagosomal Structure Responsible for Autophagosome Formation. Mol Biol Cell (2008) 19(5):2039-50. doi: 10.1091/mbc.E07-10-1048

20. Chen Y, Klionsky DJ. The Regulation of Autophagy - Unanswered Questions. J Cell Sci (2011) 124(Pt 2):161-70. doi: 10.1242/jcs.064576

21. Chan EY, Kir S, Tooze SA. siRNA Screening of the Kinome Identifies ULK1 as a Multidomain Modulator of Autophagy. J Biol Chem (2007) 282(35):2546474. doi: 10.1074/jbc.M703663200

22. Scott RC, Juhasz G, Neufeld TP. Direct Induction of Autophagy by Atg1 Inhibits Cell Growth and Induces Apoptotic Cell Death. Curr Biol (2007) 17 (1):1-11. doi: 10.1016/j.cub.2006.10.053

23. Petiot A, Ogier-Denis E, Blommaart EF, Meijer AJ, Codogno P. Distinct Classes of Phosphatidylinositol 3'-Kinases are Involved in Signaling Pathways That Control Macroautophagy in HT-29 Cells. J Biol Chem (2000) 275 (2):992-8. doi: 10.1074/jbc.275.2.992

24. Itakura E, Kishi C, Inoue K, Mizushima N. Beclin 1 Forms Two Distinct Phosphatidylinositol 3-Kinase Complexes With Mammalian Atg14 and UVRAG. Mol Biol Cell (2008) 19(12):5360-72. doi: 10.1091/mbc.E08-01-0080
25. Baehrecke EH. Autophagy: Dual Roles in Life and Death? Nat Rev Mol Cell Biol (2005) 6(6):505-10. doi: 10.1038/nrm1666

26. Liang C, Feng P, Ku B, Dotan I, Canaani D, Oh BH, et al. Autophagic and Tumour Suppressor Activity of a Novel Beclin1-binding Protein UVRAG. Nat Cell Biol (2006) 8(7):688-99. doi: 10.1038/ncb1426

27. Matsunaga K, Saitoh T, Tabata K, Omori H, Satoh T, Kurotori N, et al. Two Beclin 1-Binding Proteins, Atg14L and Rubicon, Reciprocally Regulate Autophagy At Different Stages. Nat Cell Biol (2009) 11(4):385-96. doi: $10.1038 /$ ncb1846

28. Tooze SA, Yoshimori T. The Origin of the Autophagosomal Membrane. Nat Cell Biol (2010) 12(9):831-5. doi: 10.1038/ncb0910-831

29. Obara K, Sekito T, Niimi K, Ohsumi Y. The Atg18-Atg2 Complex is Recruited to Autophagic Membranes Via Phosphatidylinositol 3-Phosphate and Exerts an Essential Function. J Biol Chem (2008) 283(35):23972-80. doi: 10.1074/ jbc.M803180200

30. Kovacs AL, Palfia Z, Rez G, Vellai T, Kovacs J. Sequestration Revisited: Integrating Traditional Electron Microscopy, De Novo Assembly and New Results. Autophagy (2007) 3(6):655-62. doi: 10.4161/auto.4590

31. Hayashi-Nishino M, Fujita N, Noda T, Yamaguchi A, Yoshimori T, Yamamoto A. A Subdomain of the Endoplasmic Reticulum Forms a Cradle for Autophagosome Formation. Nat Cell Biol (2009) 11(12):1433-7. doi: 10.1038/ncb1991

32. Yla-Anttila P, Vihinen H, Jokitalo E, Eskelinen EL. 3D Tomography Reveals Connections Between the Phagophore and Endoplasmic Reticulum. Autophagy (2009) 5(8):1180-5. doi: 10.4161/auto.5.8.10274

33. Geng J, Nair U, Yasumura-Yorimitsu K, Klionsky DJ. Post-Golgi Sec Proteins are Required for Autophagy in Saccharomyces cerevisiae. Mol Biol Cell (2010) 21(13):2257-69. doi: 10.1091/mbc.E09-11-0969

34. Hailey DW, Rambold AS, Satpute-Krishnan P, Mitra K, Sougrat R, Kim PK, et al. Mitochondria Supply Membranes for Autophagosome Biogenesis During Starvation. Cell (2010) 141(4):656-67. doi: 10.1016/j.cell.2010.04.009

35. Lynch-Day MA, Bhandari D, Menon S, Huang J, Cai H, Bartholomew CR, et al. Trs85 Directs a Ypt1 Gef, TRAPPIII, to the Phagophore to Promote Autophagy. Proc Natl Acad Sci U.S.A. (2010) 107(17):7811-6. doi: 10.1073/ pnas. 1000063107

36. Mizushima N, Noda T, Ohsumi Y. Apg16p is Required for the Function of the Apg12p-Apg5p Conjugate in the Yeast Autophagy Pathway. EMBO J (1999) 18(14):3888-96. doi: 10.1093/emboj/18.14.3888

37. Suzuki K, Kirisako T, Kamada Y, Mizushima N, Noda T, Ohsumi Y. The PreAutophagosomal Structure Organized by Concerted Functions of APG Genes is Essential for Autophagosome Formation. EMBO J (2001) 20(21):5971-81. doi: $10.1093 / \mathrm{emboj} / 20.21 .5971$

38. Fujita N, Itoh T, Omori H, Fukuda M, Noda T, Yoshimori T. The Atg16L Complex Specifies the Site of LC3 Lipidation for Membrane Biogenesis in Autophagy. Mol Biol Cell (2008) 19(5):2092-100. doi: 10.1091/mbc.E07-12-1257

39. Nakatogawa H, Ichimura Y, Ohsumi Y. Atg8, a Ubiquitin-Like Protein Required for Autophagosome Formation, Mediates Membrane Tethering and Hemifusion. Cell (2007) 130(1):165-78. doi: 10.1016/j.cell.2007.05.021

40. Shi CS, Kehrl JH. MyD88 and Trif Target Beclin 1 to Trigger Autophagy in Macrophages. J Biol Chem (2008) 283(48):33175-82. doi: 10.1074/ jbc.M804478200

41. He C, Klionsky DJ. Regulation Mechanisms and Signaling Pathways of Autophagy. Annu Rev Genet (2009) 43:67-93. doi: 10.1146/annurev-genet102808-114910

42. Tindwa H, Jo YH, Patnaik BB, Noh MY, Kim DH, Kim I, et al. Depletion of Autophagy-Related Genes ATG3 and ATG5 in Tenebrio molitor Leads to Decreased Survivability Against an Intracellular Pathogen, Listeria monocytogenes. Arch Insect Biochem Physiol (2015b) 88(1):85-99. doi: 10.1002/arch.21212

43. Kim J, Kundu M, Viollet B, Guan KL. AMPK and mTOR Regulate Autophagy Through Direct Phosphorylation of Ulk1. Nat Cell Biol (2011) 13(2):132-41. doi: $10.1038 / \mathrm{ncb} 2152$

44. Yang CS, Lee JS, Rodgers M, Min CK, Lee JY, Kim HJ, et al. Autophagy Protein Rubicon Mediates Phagocytic NADPH Oxidase Activation in Response to Microbial Infection or TLR Stimulation. Cell Host Microbe (2012) 11(3):264-76. doi: 10.1016/j.chom.2012.01.018

45. Orsi A, Razi M, Dooley HC, Robinson D, Weston AE, Collinson LM, et al. Dynamic and Transient Interactions of Atg9 With Autophagosomes, But Not 
Membrane Integration, are Required for Autophagy. Mol Biol Cell (2012) 23 (10):1860-73. doi: 10.1091/mbc.E11-09-0746

46. Yamamoto H, Kakuta S, Watanabe TM, Kitamura A, Sekito T, Kondo-Kakuta C, et al. Atg9 Vesicles are an Important Membrane Source During Early Steps of Autophagosome Formation. J Cell Biol (2012) 198(2):219-33. doi: 10.1083/ jcb.201202061

47. Jo YH, Patnaik BB, Hwang J, Park KB, Ko HJ, Kim CE, et al. Regulation of the Expression of Nine Antimicrobial Peptide Genes by TmIMD Confers Resistance Against Gram-negative Bacteria. Sci Rep (2019) 9(1):10138. doi: 10.1038/s41598-019-46222-8

48. Park S, Jo YH, Park KB, Ko HJ, Kim CE, Bae YM, et al. Tmtoll-7 Plays a Crucial Role in Innate Immune Responses Against Gram-Negative Bacteria by Regulating 5 AMP Genes in Tenebrio molitor. Front Immunol (2019) 10:310. doi: 10.3389/fimmu.2019.00310

49. Patnaik BB, Patnaik HH, Seo GW, Jo YH, Lee YS, Lee BL, et al. Gene Structure, cDNA Characterization and RNAi-based Functional Analysis of a Myeloid Differentiation Factor 88 Homolog in Tenebrio molitor Larvae Exposed to Staphylococcus aureus Infection. Dev Comp Immunol (2014) 46 (2):208-21. doi: 10.1016/j.dci.2014.04.009

50. Jo YH, Kim YJ, Park KB, Seong JH, Kim SG, Park S, et al. TmCactin Plays an Important Role in Gram-negative and -Positive Bacterial Infection by Regulating Expression of 7 AMP Genes in Tenebrio molitor. Sci Rep (2017) 7:46459. doi: 10.1038/srep46459

51. Keshavarz M, Jo YH, Park KB, Ko HJ, Edosa TT, Lee YS, et al. TmDorX2 Positively Regulates Antimicrobial Peptides in Tenebrio molitor Gut, Fat Body, and Hemocytes in Response to Bacterial and Fungal Infection. Sci Rep (2019) 9(1):16878. doi: 10.1038/s41598-019-53497-4

52. Vigneron A, Jehan C, Rigaud T, Moret Y. Immune Defenses of a Beneficial Pest: The Mealworm Beetle, Tenebrio molitor. Front Physiol (2019) 10:138. doi: 10.3389/fphys.2019.00138

53. Keshavarz M, Jo YH, Edosa TT, Han YS. Two Roles for the Tenebrio Molitor Relish in the Regulation of Antimicrobial Peptides and Autophagy-Related Genes in Response to Listeria monocytogenes. Insects (2020) 11(3):188. doi: 10.3390/insects11030188

54. Jo YH, Lee JH, Tindwa H, Patnaik HH, Seong JH, Kim SG, et al. Molecular Characterization and Expression Analysis of Target of Rapamycin (TmTOR) in Coleopteran Insect Tenebrio molitor. Entomol Res (2016) 46(2):139-47. doi: 10.1111/1748-5967.12163

55. Lee JH, Jo YH, Patnaik BB, Park KB, Tindwa H, Seo GW, et al. Cloning, Expression Analysis, and RNA Interference Study of a HORMA Domain Containing Autophagy-Related Gene 13 (ATG13) From the Coleopteran Beetle, Tenebrio molitor. Front Physiol (2015) 6:180. doi: 10.3389/ fphys.2015.00180

56. Edosa TT, Jo YH, Keshavarz M, Park KB, Cho JH, Bae YM, et al. Tmatg6 Plays an Important Role in Anti-Microbial Defense Against Listeria monocytogenes in the Mealworm, Tenebrio molitor Int J Mol Sci (2020) 21(4):1232. doi: $10.3390 / \mathrm{ijms} 21041232$

57. Tindwa H, Jo YH, Patnaik BB, Lee YS, Kang SS, Han YS. Molecular Cloning and Characterization of Autophagy-Related Gene TmATG8 in Listeriainvaded Hemocytes of Tenebrio molitor. Dev Comp Immunol (2015a) 51 (1):88-98. doi: 10.1016/j.dci.2015.02.017

58. Pizarro-Cerda J. Pascale Cossart: Listeria monocytogenes, Host-Pathogen Interactions \& Beyond. Cell Microbiol (2020) 22(4):e13165. doi: 10.1111/ cmi. 13165

59. Yano T, Mita S, Ohmori H, Oshima Y, Fujimoto Y, Ueda R, et al. Autophagic Control of Listeria Through Intracellular Innate Immune Recognition in Drosophila. Nat Immunol (2008) 9(8):908-16. doi: 10.1038/ni.1634

60. Tindwa H, Patnaik BB, Kim DH, Mun S, Jo YH, Lee BL, et al. Cloning, Characterization and Effect of TmPGRP-LE Gene Silencing on Survival of Tenebrio molitor Against Listeria monocytogenes Infection. Int J Mol Sci (2013) 14(11):22462-82. doi: 10.3390/ijms141122462

61. Casati B, Terova G, Cattaneo AG, Rimoldi S, Franzetti E, de Eguileor M, et al. Molecular Cloning, Characterization and Expression Analysis of ATG1 in the Silkworm, Bombyx mori. Gene (2012) 511(2):326-37. doi: 10.1016/ j.gene.2012.09.086
62. Li Z, Lyu Z, Ye Q, Cheng J, Wang C, Lin T. Cloning, Expression Analysis, 20Hydroxyecdysone Induction, and RNA Interference Study of Autophagyrelated Gene 8 From Heortia vitessoides Moore. Insects (2020) 11(4):245. doi: $10.3390 /$ insects 11040245

63. Xiao Q, Wang L, Zhou XL, Zhu Y, Dong ZQ, Chen P, et al. BmAtg13 Promotes the Replication and Proliferation of Bombyx mori Nucleopolyhedrovirus. Pestic Biochem Physiol (2019) 157:143-51. doi: 10.1016/j.pestbp.2019.03.016

64. Tinartis EP, Goncu E, Koc K. Apoptotic and Autophagic Characteristics of Perivisceral Fat Body Remodeling of the Greater Wax Moth Galleria mellonella and Effects of Juvenile Hormone Analog, Fenoxycarb, on These Processes. Insect Biochem Physiol (2021) 107:e21780. doi: 10.1002/arch.21780

65. Kazek M, Kaczmarek A, Wronska AK, Bogus MI. Conidiobolus coronatus Induces Oxidative Stress and Autophagy Response in Galleria mellonella Larvae. PloS One (2020) 15(2):e0228407. doi: 10.1371/journal.pone.0228407

66. Santos-Araujo S, Bomfim L, Araripe LO, Bruno R, Ramos I, Gondim KC. Silencing of ATG6 and ATG8 Promotes Increased Levels of Triacylglycerol (TAG) in the Fat Body During Prolonged Starvation Periods in the Chagas Disease Vector Rhodnius prolixus. Insect Biochem Mol Biol (2020) 127:103484. doi: $10.1016 /$ j.ibmb.2020.103484

67. Moy RH, Gold B, Molleston JM, Schad V, Yanger K, Salzano M-V, et al. Antiviral Autophagy Restricts Rift Valley Fever Virus Infection and is Conserved From Flies to Mammals. Immunity (2014) 40(1):51-65. doi: 10.1016/j.immuni.2013.10.020

68. Liu X-M, Yamasaki A, Du X-M, Coffmann VC, Ohsumi Y, Nakatogawa H, et al. Lipidation-Independent Vacoular Functions of Atg8 Rely on its Noncanonical Interaction With a Vacoule Membrane Protein. eLife (2018) 7:e41237. doi: 10.7554/eLife.41237

69. Yu YL, Zhang MT, Huo Y, Tang JL, Liu Q, Chen XY, et al. Laodelphax striatellus Atg8 Facilitates Rice Stripe Virus Infection in an AutophagyIndependent Manner. Insect Sci (2021) 28(2):315-29. doi: 10.1111/17447917.12771

70. Kim CE, Park KB, Ko HJ, Keshavarz M, Bae YM, Kim B, et al. Aedes albopictus Autophagy-Related Gene 8 (AaAtg8) is Required to Confer Anti-Bacterial Gut Immunity. Int J Mol Sci (2020) 21(8):2944. doi: 10.3390/ijms/21082944

71. Giri S, Shaha C. Leishmania Donovani Parasite Requires Atg8 Protein for Infectivity and Survival Under Stress. Cell Death Dis (2019) 10(11):808. doi: 10.1038/s41419-019-2038-7

72. Li S, Xu J, Xu X, Ma W, Tian L, Li K. Functional Identification of Bombyx mori Atg13 in Autophagy. Insect Biochem Physiol (2020) 105(1):e21718. doi: $10.1002 /$ arch. 21718

73. Nagy P, Karpati M, Varga A, Pircs K, Venkei Z, Takats S, et al. Atg17/FIP200 Localizes to Perilysosomal Ref(2)P Aggregates and Promotes Autophagy by Activation of Atg1 in Drosophila. Autophagy (2014) 10(3):453-67. doi: 10.4161 /auto.27442

74. Alers S, Loffler AS, Wesselborg S, Stork B. The Incredible Ulks. Cell Commun Signal (2012) 10(1):7. doi: 10.1186/1478-811X-10-7

75. Nakamoto M, Moy RH, Xu J, Bambina S, Yasunaga A, Shelly SS, et al. Virus Recognition by Toll-7 Activates Antiviral Autophagy in Drosophila. Immunity (2012) 36(4):658-67. doi: 10.1016/j.immuni.2012.03.003

76. Santana RAG, Oliveira MC, Cabral I, Silva Junior RCA, de Sousa DRT, Ferreira L, et al. Anopheles aquasalis Transcriptome Reveals Autophagic Responses to Plasmodium vivax Midgut Invasion. Parasit Vectors (2019) 12 (1):261. doi: 10.1186/s13071-019-3506-8

Conflict of Interest: The authors declare that the research was conducted in the absence of any commercial or financial relationships that could be construed as a potential conflict of interest.

Copyright (c) 2021 Jo, Lee, Patnaik, Keshavarz, Lee and Han. This is an open-access article distributed under the terms of the Creative Commons Attribution License (CC BY). The use, distribution or reproduction in other forums is permitted, provided the original author(s) and the copyright owner(s) are credited and that the original publication in this journal is cited, in accordance with accepted academic practice. No use, distribution or reproduction is permitted which does not comply with these terms. 